\title{
Corona and EU Economic Law:
}

\section{Competition and Free Movement in Times of Crisis}

Friso Bostoen, Nina Colpaert, Wouter Devroe, Joris Gruyters, Lennard Michaux and Liesbet Van Acker*

The outbreak of the coronavirus - and the responses of governments and businesses to combat the medical and economic crisis it entails - raise a number of urgent questions, many of which concern European economic law, ie the competition rules and free movement provisions. Can businesses cooperate to guarantee the supply of essential items or a vaccine notwithstanding the cartel prohibition of Article 101 TFEU? Is the excessive price doctrine of Article 102 TFEU a match for the price increases caused by hoarding behaviour? Can competition authorities continue to assess mergers, and might they even become more sympathetic to certain arguments such as the failing firm defence and industrial policy considerations? Under which conditions are Member States allowed to grant aid to undertakings that face economic difficulties due to the crisis? Can Member States prohibit the export of medical supplies to other Member States, and can they close their borders for European citizens? And how much freedom do public procurement rules leave governments to quickly conclude contracts for essential supplies? This article addresses these pressing questions in a comprehensive manner. It situates the numerous guidance documents adopted by the European Commission within the broader framework of EU economic law and then evaluates the compatibility of the public and private corona-related measures with that framework. The aim is to offer a legal guide for governments and businesses combatting the corona crisis.

Keywords: corona; EU economic law; competition law; internal market law; public procurement

\section{Introduction}

To combat the outbreak of the coronavirus - and its economic fallout-EU Member States have been engaged in an intense regulatory effort. Governments have granted large amounts of State aid to struggling undertakings, prohibited the export of medical supplies to other Member States, closed their borders to other EU citizens, and significantly expedited their public procurement processes to acquire essential supplies. Undertakings have reacted to the crisis in their own way, eg by cooperating to guarantee the supply of essential items or to develop a vaccine, and by charging high prices for sought-after supplies. Despite the economic crisis - and sometimes because of it - some undertakings are merging with or acquiring others.
While many aspects of life are put on hold by the corona crisis, the applicability of EU law is not. The primary instruments governing the above responses of government and business are internal market law (the four freedoms) and competition law (antitrust and State aid). While the dichotomy is not as strict, one can say that the four freedoms (of goods, ser-

DOI: $10.21552 /$ core/2020/2/4

* All authors are affiliated with the Institute for Consumer, Competition \& Market at the KU Leuven (University of Leuven), either as full professor (Wouter Devroe) or as PhD researchers (other authors). Friso Bostoen is also a fellow of the Research Foundation - Flanders (FWO). Correspondence: < friso.bostoen@kuleuven.be>. This article originates from a series of blog posts published on the CoRe Blog, see $<$ https://coreblog.lexxion.eu/> and is updated until 19 April 2020 (all links have been last accessed on that date as well). 
vices, citizens and workers, and capital) as well as State aid law circumscribe the responses of Member States, while the antitrust rules (the cartel, monopoly, and merger provisions) regulate the conduct of undertakings. This article comprehensively examines how these two bodies of law (which can be referred to as 'EU economic law') restrain and stimulate both public and private responses to the corona crisis.

Authorities, and the European Commission (EC) in particular, have been publishing guidance documents that interpret the existing instruments in light of the corona crisis, and commentary has (rightly) focused on those. However, these often specific documents only cover a small segment of a much broader body of law, which is why we situate the EC guidance within the pre-existing framework-a framework that consists of not only law and jurisprudence, but also guidances adopted previously (eg in response to the economic and financial crisis that started in 2007). This exercise allows us to uncover where the EC is simply restating well-established principles, and where it is actually offering novel interpretations-and thus creating new law. Further, detailing the pre-existing framework allows us to provide guidance where the EC offers little or none (eg on excessive pricing by undertakings). Finally, guidance is only one part of the equation; it also needs to be applied. That is why we evaluate the main public and private measures adopt-

1 World Health Organization, 'Shortage of personal protective equipment endangering health workers worldwide' (WHO Newsroom, 3 March 2020) < https://www.who.int/news-room/detail/03 -03-2020-shortage-of-personal-protective-equipment-endangering -health-workers-worldwide>.

2 Gus Trompiz, 'Explainer: How the coronavirus crisis is affecting food supply' (Reuters, 3 April 2020) <https://www.reuters.com/ article/us-health-coronavirus-food-explainer/explainer-how-the -coronavirus-crisis-is-affecting-food-supply-idUSKBN21LOD2>.

3 To some extent this is already happening: Matt Apuzzo and David Kirkpatrick, 'COVID-19 changed how the world does science, together' (New York Times, 1 April 2020) <https://www.nytimes .com/2020/04/01/world/europe/coronavirus-science-research -cooperation.html>.

4 Apple, 'Apple and Google partner on COVID-19 contact tracing technology' (Press release, 10 April 2020) <https://www.apple.com/newsroom/2020/04/apple-and-google-partner-oncovid-19-contact-tracing-technology/>.

5 See eg John Newman, 'Cooperation, Competition, and COVID-19' (Truth on the Market, 15 April 2020) <https:// truthonthemarket.com/author/johnnewmanicle/s.

6 See eg Mark Kleinman, 'Coronavirus: Supermarkets float competition waiver if crisis deepens' (Sky News, 9 March 2020) <https:// news.sky.com/story/coronavirus-supermarkets-float-competition -waiver-if-crisis-deepens-11953710>. ed in response to the corona crisis against the relevant branches of EU economic law.

This article is structured as follows. We start by examining competition law, ie the prohibition of restrictive agreements (section II.), the provision on abuse of dominance (section III.), the merger control regime (section IV.), and the State aid rules (section V.). Next, we turn to internal market law, in particular free movement of goods, free provision of services, and free movement of EU citizens and workers (section VI.). Then, we discuss the public procurement rules (section VII.), before offering concluding observations (section VIII.).

\section{Article 101 TFEU: Cooperation in Times of Crisis?}

While consumers form long lines at the supermarket, stocking up on non-perishable foods and toilet paper, alarming messages seep in from the health sector warning about shortages of medicines, facemasks and other medical supplies. ${ }^{1}$ In addition to this asymmetric demand shock, the disruption of supply chains by quarantine measures has resulted in a general supply shock. To address these difficulties, there is an ever-louder call-primarily from the retail and medical sector-to allow for cooperation between competitors, which Article 101 TFEU generally prohibits. This section examines which kind of cooperation is allowed under the EU's cartel prohibition - a question on which the EC recently offered more guidance.

\section{Cooperation under Article 101 TFEU}

Cooperation in healthcare is indispensable, but supermarkets and other businesses might also want to cooperate to handle the effects of panic buyers and a disrupted supply chain. ${ }^{2}$ Other essential services, such as laboratories, could quicken the development of a vaccine if they share their findings. ${ }^{3}$ Furthermore, less obvious forms of cooperation are emerging, such as Apple and Google's joint effort to develop technology supporting contact tracing apps. ${ }^{4} \mathrm{Sev}$ eral voices-from both academia ${ }^{5}$ and business ${ }^{6}$ - are calling for a softening or suspension of the competition rules so as not to hamper (necessary) cooperation. EU competition law generally 
prevents collaboration between competitors, but one might wonder how flexible it is in times of crisis.

Article 101(1) TFEU prohibits 'all agreements between undertakings ... and concerted practices which may affect trade between Member States and which have as their object or effect the prevention, restriction or distortion of competition within the internal market'. The Horizontal Guidelines specify that, in all circumstances, undertakings should refrain from sharing their intentions for future prices and quantity changes. ${ }^{7}$ Although it might be tempting for undertakings to share or even coordinate their plan of action, this is considered a restriction 'by object', which means that a competition authority does not even have to examine its effects to consider it unlawful. ${ }^{8}$ Undertakings, including supermarkets, should thus be aware that contacts with competitors-even if the intention is noble ${ }^{9}$ - can and often will infringe the cartel prohibition.

Emphasizing that undertakings should still adhere to the competition rules in general is stating the obvious. Nevertheless, the EC and other competition authorities have been blowing hot and cold: on the one hand, they confirm that the competition rules remain applicable and will be enforced; on the other hand, they are issuing statements on how they may be interpreted flexibly. ${ }^{10}$ In any case, the prohibition of Article 101(1) TFEU is still applicable, and undertakings have to be wary of any form of coordination. However, certain corona collaborations may fall under Article 101(3) TFEU, which provides for an exemption from the prohibition if the collaboration produces efficiency benefits, allows consumers a fair share of those benefits, is indispensable, and does not eliminate competition. In Pasteur Mérieux-Merck, the EC has accepted the efficiency gains that derive from cooperating in favour of public health. ${ }^{11}$ However, two problems arise when generalizing this decision. First, this was decided more than 20 years ago with little clarification since. Second, the case concerned vaccines, which have a more direct connection to public health than, for example, products in supermarkets. Although it has been argued that the exemption does include other essential supplies such as food, ${ }^{12}$ we believe this is only the case if shortages become severe enough to affect public health, in which case cooperation may indeed become 'indispensable' and therefore allowed.
Further, the exemption of Article 101(3) TFEU has been specified in several 'block exemptions'. In light of the corona crisis, one block exemption is particularly relevant. When universities and laboratories work together to develop a vaccine, they can justify doing so under the Research and Development Block Exemption Regulation. ${ }^{13}$ If the crisis worsens, undertakings might call for a similar block exemption for cooperation between supermarkets, tech companies or other undertakings.

\section{Temporary Antitrust Framework}

On 8 April 2020, the EC adopted a 'Temporary Framework for assessing antitrust issues related to business cooperation in response to situations of urgency stemming from the current COVID-19 outbreak' (Temporary Antitrust Framework). ${ }^{14}$ As an amplification of Article 101 TFEU, the framework offers guidance on cooperation in times of crisis so as to 'avoid the risk of shortages of essential and scarce products and services.' ${ }^{15}$

7 EC, Guidelines on the applicability of Article 101 of the Treaty on the Functioning of the European Union to horizontal co-operation agreements (Communication) [2011] OJ C 11/1, para 86.

8 OECD, 'Information exchanges between competitors under competition law' (Policy Roundtable) DAF/COMP(2010)37.

9 See, for example, ACM, Analysis of the sustainability arrangements concerning the 'Chicken of Tomorrow' ACM/DM/2014/206028.

10 EC, 'Temporary Framework for assessing antitrust issues related to business cooperation in response to situations of urgency stemming from the current COVID-19 outbreak' (Communication) $\operatorname{COM}(2020) 3200$ ('Temporary Antitrust Framework'), paras 15 and 20; nationally, see eg Luxembourg Competition Council, 'Impact of COVID-19 on the actions of the Council of competition' (31 March 2020) <https://concurrence.public.lu/dam-assets/ fr/actualites/2020/2020-03-31-Document-d-orientation -entreprises-COVID-19.pdf >.

11 Pasteur Mérieux-Merck (Case IV/34.776) Commission Decision 94/770/EC [1994] OJ L 309/0001

12 Nicole Kar and Emma Cochrane, 'COVID-19 and competition law: rapid regulator responses', (Linklaters, 13 march 2020) $<$ https://www.linklaters.com/en/insights/blogs/linkingcompetition/ 2020/march/covid-19-and-competition-law-rapid-regulator -responses>.

13 Commission Regulation (EU) No 1217/2010 of 14 December 2010 on the application of Article 101(3) of the Treaty on the Functioning of the European Union to certain categories of research and development agreements [2010] OJ L 335/36.

14 Temporary Antitrust Framework, para 2.

15 EC, 'Commission provides guidance on allowing limited cooperation among businesses, especially for critical hospital medicines during the coronavirus outbreak' (Press release, 8 April 2020) IP/20/618. 


\section{a. Antitrust Assessment During the Corona Crisis}

To address the different forms of cooperation mushrooming due to the corona pandemic, the EC divides its guidance into three parts: cooperation organized by trade associations and the like, cooperation by individual companies, and cooperation imposed by the government.

First, the EC focuses on cooperation organized by a trade association and provides five examples of practices they may be entrusted with, namely (i) $\mathrm{CO}^{-}$ ordinate joint transport, (ii) identify essential medicines, (iii) aggregate production and capacity information, (iv) predict demand and identify supply gaps, and (v) share aggregate supply gap information and allow undertakings to indicate whether they can fill that gap. ${ }^{16}$ The EC emphasizes that those forms of cooperation were-under certain conditions-already allowed. One of the conditions accentuated is the prohibition to communicate any individual company information to competitors. ${ }^{17}$ Evidently, the EC prefers cooperation facilitated by a trade association over one-on-one firm cooperation.

Still, the EC realizes that 'cooperation ... might even need to go further to overcome critical supply

16 Temporary Antitrust Framework, para 12.

17 ibid, para 13.

18 ibid, para 14.

19 ibid, para 15.

20 ibid.

21 Cases C-359/95 P and C-379/95 P Ladbroke Racing [1997] ECR I-06265, paras 33 and 34, the case-law cited there and subsequent case-law.

22 Temporary Antitrust Framework, para 16.

23 See ibid, para 12 ('cooperation in the health sector'), para 14 ('Cooperation in the health sector') and para 15 ('certain coordination of which site produces which medicines'); by contrast, see para 4 ('as well as between undertakings active in other sectors') and para 17 ('guidance to undertakings and trade associations').

24 See eg Danish Competition Council, 'Communication from the Competition Council on the competition rules and COVID-19' (23 March 2020); Czech Republic Competition Office, 'Binding approach of the office for the protection of competition to address the impact of the covid-19 pandemic on competition in the Czech Republic' (9 April 2020) <https://www.uohs.cz/cs/ hospodarska-soutez/aktuality-z-hospodarske-souteze/2765 -zavazny-pristup-uradu-pro-ochranu-hospodarske-souteze-k -reseni-dopadu-pandemie-covid-19-na-hospodarskou-soutez-v -ceske-republice.html>.

25 Council Regulation (EC) $1 / 2003$ on the implementation of the rules on competition laid down in Articles 81 and 82 of the Treaty [2002] OJ L 1/1. shortages', particularly in the health sector. ${ }^{18}$ Therefore, it also zooms in on direct cooperation between undertakings, such as coordination of production, stock management, and distribution, which implies sharing commercially sensitive information. Although normally illegal, the EC affirms that cooperation in line with the laid-out conditions does not violate Article 101 TFEU or will at least not be an enforcement priority. For this to apply, the measures need to be temporary, designed and objectively necessary to increase output, and not exceed what is strictly necessary to address or avoid a supply shortage. Moreover, cooperating companies need to document all their agreements and practices. ${ }^{19}$

Lastly, governments can legitimize cooperation between companies. Encouragement or coordination of cooperation by governments will be taken into account to conclude that the collaboration is legal. ${ }^{20}$ Although this is already established case law, ${ }^{21}$ the EC also emphasizes that competition law is not be violated if governments force companies to cooperate. $^{22}$

The Temporary Antitrust Framework is unique: while the EC has published several temporary state aid frameworks, this is a first for antitrust. However, one important question mark appears: what is the scope of the Temporary Antitrust Framework? While the EC describes the current problems in general terms and mentions several sectors, most of the imperative parts of the framework seem only applicable to the health sector. ${ }^{23}$ This unclarity leads to uncertainty, the exact opposite of the raison d'être of the framework. National competition authorities (NCAs) have, by contrast, worded their national equivalents of the framework in broader terms. ${ }^{24}$ In addition, the framework is not exactly innovative either: except for the enforcement priorities (as well as the reintroduction of comfort letters, see infra), every aspect had already been established, either in case law or in other instruments.

\section{b. Comfort Letters}

Since 2003, companies have to self-assess the legality of their practices and agreements, without help from the EC through so-called 'comfort letters'. ${ }^{25}$ However, because of the unprecedented nature of the corona crisis, the EC is once more providing ad hoc comfort 
letters, albeit exceptionally and at its sole discretion. ${ }^{26}$ The EC has already revived the practice, for example, by issuing a comfort letter to 'Medicines for Europe', a trade association of generic pharmaceuticals producers. ${ }^{27}$ The letter allows-under some further requirements-both members and non-members of the association to cooperate in order to target potential shortages of critical hospital medicines. Besides the formal letters of comfort, the EC has also set up an email address and webspace for questions. At first, comfort letters appear to be providing legal certainty for companies, but old criticisms-such as the impact on third-party rights, their legal value and their reviewability—-will probably resurface. ${ }^{28}$

\section{Article 102 TFEU: The Return of the Excessive Pricing Doctrine?}

While panic buying has affected a range of products, two items - hand sanitizer and facemasks - have been in particularly high demand (and short supply), which drives up prices. One Belgian supermarket was selling facemasks at $€ 28$ apiece, for example. ${ }^{29}$ Even items that did not experience a spike in demand have seen price increases: in Belgium, the general price level at various large supermarkets climbed $5-6 \%{ }^{30}$ From a competition law perspective, one may wonder whether any such price increases qualify as an abuse of dominance in the sense of Article 102 TFEU.

\section{Does Competition Law Reach Those Increasing Prices?}

Consumers' hoarding behaviour is generally motivated by personal concerns-for the resulting price increases, there is no individual accountability, at least under competition law. However, these price increases are implemented by supermarkets and other retailers, which most definitely do fall under the competition law definition of 'undertaking. ${ }^{31}$ Interestingly, there is a third category of players that are neither simple consumers, nor sophisticated retailers. These 'superhoarders' seek to profit from the corona crisis by emptying shelves - in particular of hand sanitizer and facemasks - to then resell these products at a premium. One American was able to procure no less than 17,700 bottles of hand sanitizer, for example. $^{32}$ The preferred way to sell these sought-after items is through online marketplaces such as Amazon and eBay, where sellers can set their prices freely. In the UK, for instance, hand sanitizer bottles 'are being sold online for up to 5000[\%] more than the original price' (large bottles were going for up to $€_{165)}{ }^{33}$ Even though some designate the marketplaces themselves as the sellers, they are mistaken: these platforms only facilitate sales. ${ }^{34}$ However, the (often small) sellers on these platforms also fall under the broad definition of 'undertaking', ie 'every entity engaged in an economic activity, regardless of the legal status of the entity and the way in which it is financed. ${ }^{35}$ Thus, there is no issue clearing this

26 Temporary Antitrust Framework, para 18.

27 Medicines for Europe, 'Medicines for Europe welcomes EC decision to enable secure supply of hospital medicines' (Press release, 8 April 2020) <https://www.medicinesforeurope.com/wp -content/uploads/2020/04/Medicines-for-Europe-Press-release -European-antitrust-guidance-08042020.pdf>.

28 Borys Wodz, 'Comfort letters and other informal letters in E.C. competition proceedings - why is the story not over?' (2000) 21 European Competition Law Review 159.

29 Gudrun Steen, 'Carrefour grijpt in: mondmaskers van 28 euro per stuk gisteren nog aan 17,50 euro, vandaag niet meer verkrijgbaar' (Het Laatste Nieuws, 6 March 2020) <https://www.hln.be/in-de -buurt/diksmuide/carrefour-grijpt-in-mondmaskers-van-28-euro -per-stuk-gisteren-nog-aan-17-50-euro-vandaag-niet-meer -verkrijgbaar ad0600f4/>.

30 'Corona-effect op de supermarktprijzen: tot ruim 6\% duurder' (Test-Aankoop, 3 April 2020) <https://www.test-aankoop.be/ familie-prive/supermarkten/nieuws/corona-effect-op -supermarktprijzen>. The price increase is explained, at least in part, by the national prohibition of discounting (adopted to curb hoarding behaviour), see Ministerieel Besluit houdende drin-

gende maatregelen om de verspreiding van het coronavirus COVID-19 te beperken, C-2020/20705, 3 April 2020, art 1 §3.

31 Case C-41/90 Klaus Höfner and Fritz Elser v Macrotron [1991] ECR I-1979, para 21.

32 Jack Nicas, 'He has 17,700 bottles of hand sanitizer and nowhere to sell them' (The New York Times, 17 March 2020) <https://www .nytimes.com/2020/03/14/technology/coronavirus-purell-wipes -amazon-sellers.html>.

33 Sahar Nazir, 'Ebay selling hand sanitisers 5000\% more than original price' (Retail Gazette, 8 March 2020) <https://www.retailgazette.co.uk/blog/2020/03/coronavirus-ebay-selling-hand-sanitisers-5000-original-price/>; ' \$194 for hand sanitizer?' (Reuters, 5 March 2020) <https://www.reuters.com/article/us-health-coronavirus-cma/194-for-hand-sanitizer-you-must-be-jokingidUSKBN20S1TU>.

34 On the operation of (online) platforms, see Jean Charles Rochet and Jean Tirole, 'Platform competition in two-sided markets' (2003) 1 Journal of the European Economics Association 990 and subsequent scholarship.

35 Case C-41/90 Klaus Höfner and Fritz Elser v Macrotron [1991] ECR I-1979, para 21. 
first hurdle: sellers—-large or small—are within the scope of competition law.

\section{When Do Excessive Prices Become Abusive?}

A more difficult question is when high prices become abusive within the meaning of Article 102 TFEU (or their national equivalent). While this question has been answered through decades of case law, the current legal test still leaves ample room for interpretation. Many competition authorities have issued warnings regarding excessive prices in times of crisis, but some of these warnings may amount to bluff, given the difficult-to-meet criteria of the excessive pricing doctrine.

\section{a. Excessive Pricing Theory: Defining 'Unfairness'}

The bar for excessive pricing cases is high. First, the seller in question must be dominant. A dominant position is rebuttably presumed in case of market shares

36 Case C-62/86 AKZO Chemie v Commission [1991] ECR I-3359, para 60.

37 Case 27/76 United Brands v Commission [1978] ECR 207, paras 108-10. National competition laws may be stricter. German competition law, for example, already presumes dominance in case of market shares exceeding $40 \%$, see $\$ 18(4)$ Act against Restraints of Competition.

38 See eg UNCTAD Secretariat, 'Enforcement of competition policy in the retail sector: competition issues in the food retail chain' (Note TD/B/C.I/CLP/38) 2016, 3.

39 Case 27/76 United Brands Company v Commission [1978] ECR 207, para 250; see most recently Case C-177/16 Autortiesibu un komunicešanas konsultaciju agentura v Latvijas Autoru apvieniba $\checkmark$ Konkurences padome EU:C:2017:689, para 35.

40 Case 27/76 United Brands Company v Commission [1978] ECR 207, para 252.

41 OECD Working Party No. 2 on Competition and Regulation, Excessive Prices (Contribution of the European Union) DAF/COMP/WP2/WD (2011) 54, 11-2.

42 Applying this test in 'normal' times is already a challenge, see extensively Frédéric Jenny, 'Abuse of dominance by firms charging excessive or unfair prices: an assessment' in Yannis Katsoulacos and Frédéric Jenny, Excessive pricing and competition law enforcement (Springer 2018), 5-70.

43 The UK competition authority has been particularly concerned with excessive pricing cases, see OECD, 'Excessive pricing in pharmaceutical markets' (Note by the United Kingdom) DAF/COMP/WD(2018)110, describing cases regarding price increases of up to $2.600 \%$, and of $6.000 \%$ and $12.000 \%$. See also the Italian competition authority's Aspen case regarding price increases of $257 \%$ to $1540 \%$, described (in English) in OECD 'Excessive pricing in pharmaceutical markets' (Note by Italy) DAF/COMP/WD(2018)106, 6-9. exceeding $50 \% ;^{36}$ above $40 \%$, there is an indication of dominance. ${ }^{37}$ This hurdle is already difficult when considering the relevant sellers. Supermarkets are often in a strong but not dominant position, if only because there are usually 3-4 large chains competing in every country. ${ }^{38}$ Superhoarders, for their part, are nowhere near dominant: even if certain items become scarce, every seller only commands a small part of the total supply.

Second, the price must be excessive or-in the words of Article 102 TFEU-'unfair'. According to the ECJ, a price is 'excessive because it has no reasonable relation to the economic value of the product supplied'. ${ }^{39}$ It operationalized this basic formula in a two-pronged test: first, one has to examine whether the profit margin (price minus cost) is excessive; if that is the case, one has to check whether the price is 'either unfair in itself or when compared to competing products' ${ }^{40}$ This comparison can take many forms, but the reference price is often (i) the price charged by the company in different markets; (ii) the price charged by the company at a different point in time; and/or (iii) the price charged for comparable products by other companies in different markets. ${ }^{41}$

Applying this test in times of crisis is not easy. ${ }^{42}$ Firstly, what is the current 'economic value' of the products that are in high demand, such as facemasks and hand sanitizer? One could argue their value is now high, which would mean that a correspondingly high price is justified. Moving on to the twopronged test, one has to look into the profit margin from these sought-after items. If the (re)seller also had to pay a premium for the items because supplies are limited, the profit margin may not be excessive. And if it is, the end result of the test is determined by the reference point chosen for comparison. High prices may not seem excessive when compared to the price charged in other markets or by other companies, simply because the crisis has driven up prices generally.

However, there are also arguments that an excessive pricing case in this scenario could be successful. Firstly, if the past (say, a year ago) is used as the relevant reference point, prices that are high due to the corona crisis will more easily appear excessive. Looking at several cases on pharmaceuticals, prices have been found abusive when they increased with a couple $100 \%$, and-more often-when they increased with a couple of $1000 \%{ }^{43}$ Selling hand san- 
itizer for $5000 \%$ of the original retail price is in line with such cases. Further, competition authorities could focus not on a reference point but on whether the price is unfair in itself. ${ }^{44}$ The bar could, in that case, be lower, although such a vague standard has costs in terms of legal certainty. Finally, the ECJ has recognized that 'other ways may be devised ... of selecting the rules for determining whether the price of a product is unfair', giving NCAs some discretion. $^{45}$

\section{b. Excessive Pricing Practice: Forewarned Is Forearmed}

Competition authorities generally shy away from cases of exploitative abuse, such as excessive pricing; they are mostly focused on instances of exclusionary abuse. ${ }^{46}$ This state of affairs has changed markedly due to the corona crisis, which led more than a dozen NCAs to issue warnings to those seeking to profit by exploiting consumers. ${ }^{47}$ The ECN also weighed in with a joint statement stressing that 'it is of utmost importance to ensure that products considered essential to protect the health of consumers in the current situation (eg facemasks and sanitising gel) remain available at competitive prices' and that action will be taken against companies taking advantage of the situation by abusing their dominance. ${ }^{48}$

44 In its Aspen case, for example, the Italian competition authority looked at whether there were any explanations for the price increase, such as increased costs, higher quality, or the need to recover R\&D investments. See OECD, Excessive pricing in pharmaceutical markets (Note by Italy) DAF/COMP/WD(2018)106, 6-9.

45 Case 27/76 United Brands Company v Commission [1978] ECR 207, para 253.

46 Competition authorities shy away from excessive pricing cases because they are viewed as ill-suited to carry out price controls and because of the belief that markets self-correct pricing excesses, see Damien Geradin, 'The necessary limits to the control of "excessive" prices by competition authorities - A view from Europe' (2007) Tilburg University Legal Studies Working Paper, 3.

47 CMA, 'COVID-19: sales and pricing practices during Coronavirus outbreak' (Press release, 5 March 2020) <https://www.gov.uk/ government/news/covid-19-sales-and-pricing-practices-during -coronavirus-outbreak>; HCC, 'Implementation of competition rules in special social and economic conditions' (Press release, 7 March 2020) <https://www.epant.gr/enimerosi/deltia-typou/item/ 831-deltio-typou-antiantagonistikes-praktikes-se-eidikes -koinonikes-kai-oikonomikes-synthikes.html>; Conseil de la concurrence, 'Impact du COVID-19 sur les actions du Conseil de la concurrence' (Document d'orientation à destination des entreprises, 31 March 2020); CNMC, 'COVID-19 complaints and queries involving the application of competition rules' (Press
Some competition authorities have translated words into action. The UK competition authority (CMA) 'has already contacted traders and platforms regarding excessive pricing of hand sanitiser. ${ }^{49}$ The Italian competition authority (AGCM) has initiated proceedings regarding the unjustified and significant increase in the prices recorded for the sale of [health and hygiene] products...$^{50}$ The Greek competition authority (HCC) has opened a similar investigation. ${ }^{51}$ However, two questions remain. Firstly, while there may be some flexibility in determining the excessiveness of a price, establishing dominance remains an issue-and competition authorities continue to recognize this prerequisite. ${ }^{52}$ Secondly, investigations - even when sped up — tend to have a duration that is problematic in times of crisis. To remedy this, competition authorities have started looking at alternatives. The CMA, for example, has stated it may be seeking emergency powers. ${ }^{53}$ The AGCM, for its part, has been making broad use of interim measures.

\section{Looking Beyond Competition Law: The Consumer Law Lifeline}

Certain competition authorities do not only enforce competition law but also consumer law, ${ }^{54}$ in particular the (national implementation of) the Unfair Com-

release, 7 April 2020) <https://www.cnmc.es/balance-buzon -covid-7-abril-20200407>. See also Temporary Antitrust Framework, para 20.

$48 \mathrm{ECN}$, 'Application of competition law during the Corona crisis' (Joint Statement) 2020.

49 CMA, 'CMA launches COVID-19 taskforce' (Press release, 20 March 2020).

50 AGCM, 'Coronavirus, the Authority begins investigating Amazon and eBay for misleading claims and excessive price increases' (Press release, 12 March 2020) < https://en.agcm.it/en/media/press -releases/2020/3/ICA-Coronavirus-the-Authority-begins -investigating-Amazon-and-eBay-for-misleading-claims-and -excessive-price-increases>.

51 HCC, 'Investigation in healthcare materials' (Press release, 21 March 2020) <https://www.epant.gr/en/enimerosi/press-releases/ item/840-press-release-investigation-in-healthcare-materials.html>.

52 Cf references in footnotes 47-48.

53 CMA, 'CMA launches COVID-19 taskforce' (Press release, 20 March 2020) <https://www.gov.uk/government/news/cma -launches-covid-19-taskforce>.

54 For an overview, see Kati Cseres, 'Integrate or separate: institutional design for the enforcement of competition law and consumer law' (Amsterdam Law School Research Paper No 2013-03, 2020). 
mercial Practices Directive (UCPD).$^{55}$ Reliance on consumer law avoids some of the difficulties of competition law, in particular the requisite of dominance. However, the UCPD is not (directly) aimed at excessive prices, but rather at deceptive and aggressive practices. ${ }^{56}$ There is no shortage of such practices, which seek to capitalize on the fears of consumers, and the UCPD provides an important remedy to those ${ }^{57}$ However, when consumer law is ostensibly relied on to remedy a competition law issue such as excessive prices, there is thus a risk of muddying the waters of both branches of law. ${ }^{58}$ At the same time, consumer law may serve as a 'safety net' for actions that are difficult to justify under competition law, thereby increasing deterrence.

\section{Power to the Producer, the Platform, and the Politician}

We should not only look to competition authorities to solve the issue of excessively priced products. First, manufacturers that wish to prevent distributors from unduly increasing the price of their products are empowered to do so. ${ }^{59}$ In particular, the Vertical Block Exemption Regulation allows them to impose maximum retail prices on distributors, at least if the market share of neither party exceeds $30 \% .{ }^{60}$ The ECN has reminded manufacturers of this possibility, ${ }^{61}$ and the Greek competition authority HCC has confirmed

55 Directive 2005/29/EC of the European Parliament and of the Council of 11 May 2005 concerning unfair business-to-consumer commercial practices in the internal market [2005] O] L149/22.

56 Some practices combine deception with an excessive price, eg when '[t]raders claim that due to the increased demand for protective masks, which they offer at a price of up to $600 \%$ higher than the normal price, are hard to find.' See CPC, 'Stopping scams and tackling unfair business practices on online platforms in the context of the Coronavirus outbreak in the $\mathrm{EU}^{\prime}$ (Common Position) 2020, 3.

57 ibid

58 The risk is exacerbated when 'hybrid' authorities do not specify which law they are relying on. The AGCM, for example, has not specified on which basis it is investigating misleading claims and price increases, see AGCM, 'Coronavirus, the Authority begins investigating Amazon and eBay for misleading claims and excessive price increases' (Press release, 12 March 2020) <https://en .agcm.it/en/media/press-releases/2020/3/ICA-Coronavirus-the -Authority-begins-investigating-Amazon-and-eBay-for-misleading -claims-and-excessive-price-increases>.

59 It appears that manufacturers are concerned about the price of their products, see eg Lauren Hirsch, 'Group representing Coke, Clorox, other brands urges Attorney General Barr to fight coronavirus price gouging' (CNBC, 9 March 2020) <https://www.cnbc it will not take action against such maximum retail prices. ${ }^{62}$ Of course, maximum prices can only bind retailers, not the resellers on online marketplaces. However, marketplaces such as Amazon have been trying to halt the tide of overpriced and misleading products by removing product listings and banning sellers. ${ }^{63}$ Finally, if all else fails, Member States can start regulating the prices of certain goods; France, for example, has set a maximum price for hand sanitizer. $^{64}$

\section{Merger Control: Fear of Failing and Foreign}

\section{General}

Besides the rise of cooperation and excessive prices, the corona pandemic also affects a third pillar of the EU competition framework: merger control. The EU and its Member States consider merger control mandatory, meaning that the relevant authorities have to clear every notifiable merger. ${ }^{65}$ The current crisis has both direct effects (different procedures, extended deadlines, and delays) and indirect effects (less and different mergers).

When the virus started to spread, NCAs quickly started to readjust their normal merger procedures in two ways. First, several NCAs adapted their dayto-day operations, including closing their offices, re-

.com/2020/03/09/coronavirus-coke-clorox-other-brands-urge -attorney-general-barr-to-fight-price-gouging.html>.

60 Commission Regulation (EU) No 330/2010 of 20 April 2010 on the application of Article 101(3) of the Treaty on the Functioning of the European Union to categories of vertical agreements and concerted practices [2010] OJ L102/1, arts 2, 3 and 4.

61 ECN, 'Application of competition law during the Corona crisis' (Joint Statement) 2020.

62 HCC, Implementation of competition rules in supply contracts and distribution agreements' (Press release, 16 March 2020) <https://www.epant.gr/enimerosi/deltia-typou/item/836-deltio -typou-efarmogi-kanonon-antagonismoy.html>

63 See eg Zoe Wood, 'Amazon struggles to halt tide of coronavirus profiteers' (The Guardian, 3 March 2020) <https://www theguardian.com/technology/2020/mar/03/amazon-struggles-to -halt-tide-of-coronavirus-profiteers>. The UCPD, as well as the ECommerce Directive, may actually oblige them to do so, see CPC, 'Stopping scams and tackling unfair business practices on online platforms in the context of the Coronavirus outbreak in the EU' (Common Position) 2020, 1-2.

64 See Elisa Braun, 'France slaps price controls on hand sanitizer' (Politico, 4 March 2020) <https://www.politico.eu/article/france -slaps-price-controls-on-hand-sanitizer/>.

65 Council Regulation No 139/2004 on the control of concentrations between undertakings (Merger Regulation) [2004] OJ L 24/1, art 4. 
quiring documents to be submitted online and suspending hearings. ${ }^{66}$ Additionally, the NCAs announced changes to merger timelines, including the suspension of deadlines, calls to only notify urgent mergers, and warnings for delays, all of which are mainly due to difficulties to collect the information needed to assess the merger. ${ }^{67}$ While some NCAs have drafted extensive guidance, ${ }^{68}$ the EC has been rather succinct but also called for electronic submissions, and solely of urgent mergers. ${ }^{69}$

Aside from the direct effects, the corona crisis has an unprecedented impact on the European economies, thus also affecting mergers. In general, merger activity has come to a standstill in most sectors with large mergers even being cancelled. ${ }^{70}$ Nonetheless, a few sectors are still seeing merger activity, and they include both between 'winners' and 'losers' from this crisis. For example, it is no surprise that Verizon is going ahead with its acquisition of BlueJeans, a video conferencing platform. ${ }^{71}$ In addition, albeit for different reasons, the Airlines for Europe president stated that the crisis 'will accelerate the consolidation' within the airline sector. ${ }^{72}$

\section{Failing Firm Defence}

A crisis may not only entail procedural but also substantive changes to merger control, in particular when it comes to companies that have been particularly af-

66 See eg CCPC, 'COVID-19 temporary merger notification process' (Press release, 18 March 2020) <https://www.ccpc.ie/business/ covid-19-temporary-merger-notifications-process/>; CNMC, 'COVID-19: The CNMC adapts its operations in order to continue providing its services' (Press release, 12 March 2020) <https://www .cnmc.es/sites/default/files/editor_contenidos/Notas\%20de \%20prensa/2020/20200312_NP_medidas_excepcionales_eng.pdf >; FCO, 'Communication with the Bundeskartellamt (Coronavirus measures)' (Press release, 17 March 2020) <https://www .bundeskartellamt.de/SharedDocs/Meldung/EN/AktuelleMeldungen/ 2020/17_03_2020_Communication_Bundeskartellamt.html>.

67 See eg AGCM, 'Communication on the interpretation of art. 103 of the law decree 17 March 2020, n. 18' (Press release, 10 April 2020) <https://www.agcm.it/dotcmsdoc/allegati-news/200401 new.pdf>; ACM, 'ACM's oversight during the Coronavirus crisis' (press release, 18 March 2020) <https://www.acm.nl/en/ publications/acms-oversight-during-coronavirus-crisis $>$.

68 FCA, 'Adaptation of the time limits and procedures of the Autorite de la concurrence in times of health emergency' (Press release, 27 March 2020)<https://www.autoritedelaconcurrence.fr/en/press -release/adaptation-time-limits-and-procedures-autorite-de-la -concurrence-times-health $>$.

69 EC, 'Special measures due to coronavirus' (Press release, 7 April 2020) <https://ec.europa.eu/competition/mergers/covid_19.html>.

70 Greg Roumeliotis, 'Xerox abandons $\$ 35$ billion hostile bid for HP' (Reuters, 31 March 2020) <https://www.reuters.com/article/us fected by the crisis, such as airlines. As some of them face bankruptcy, they become targets for acquisition. Those acquisitions may face less strict scrutiny due to the so-called 'failing firm defence'. According to this phenomenon, the EC can wave through an otherwise problematic merger if (i) the failing firm would in the near future be forced out of the market because of financial difficulties if not taken over; (ii) there is no less anticompetitive alternative purchaser; and (iii) in the absence of a merger, the assets of the failing firm would inevitably exit the market. ${ }^{73}$

We are already seeing the failing firm defence in action. Amazon planned a significant investment in the restaurant delivery firm Deliveroo, which would reportedly give it a $16 \%$ stake in the company. The CMA was particularly skeptical of the transaction, and went as far as to open 'phase 2 ' proceedings. ${ }^{74}$ On 17 April 2020, however, the CMA provisionally cleared Amazon's acquisition of a minority shareholding in Deliveroo. ${ }^{75}$ In its approval, the CMA relied on the fact that, through restaurant closures, ' $t$ the Coronavirus ... crisis has substantially affected the market and Deliveroo's financial position', up to a point that 'Deliveroo would be likely to exit the market ... without additional funds. ${ }^{76}$ Further, besides Amazon's investment, 'Deliveroo has no alternative options available to it to preserve its business', while Deliveroo's exit from the market would negatively affect competition (only two significant players, Just Eat and Uber Eats, would remain). ${ }^{77}$ After

-hp-m-a-xerox-hlngs/xerox-abandons-35-billion-hostile-bid-for-hp -sources-idUSKBN21I3C0>; James Fontanella-Khan and Arash Massoudi, 'Dealmaking grinds to a halt on coronavirus impact' (Financial Times, 31 March 2020) <https://www.ft.com/content/ 08119ae1-b0c8-4cd3-b4b8-b38c8b252f8dW>.

71 Verizon, 'Verizon Business enters into agreement to acquire Blueleans' (press release, 16 April 2020) <https://www.verizon.com/about/news/verizon-business-enters-agreement-acquirebluejeans $>$.

72 Oscar Schneider, 'Coronavirus could speed up air transport mergers' (The Brussels Times, 3 March 2020) <https://www brusselstimes.com/all-news/98237/covid-19-could-speed-up -mergers-in-the-air-transport-sector/>.

73 Guidelines on the assessment of horizontal mergers under the Council Regulation on the control of concentrations between undertakings, OJ C 31/ 5, paras 108-11; Joined cases C-68/94 and C-30/95 Kali and Salz [1998] ECR I-1375.

74 See <https://www.gov.uk/cma-cases/amazon-deliveroo-merger -inquiry\#history $>$.

75 CMA, 'Anticipated acquisition by Amazon of a minority shareholding and certain rights in Deliveroo' (Summary of provisional findings), available ibid.

76 ibid, 6

77 ibid, 7-9. 
an assessment largely equivalent to that of the failing firm defence, the CMA thus cleared the merger. Similar merger assessments will undoubtedly follow.

\section{Foreign Direct Investments}

There is a fear that the corona crisis is an opportunity for foreign buyers to come in and scoop up companies at bargain prices. To assuage Member States' fear on this point, the EC published a guidance on the free movement of capital and on the screening of foreign direct investment (FDI), ${ }^{78}$ on which a Regulation is yet to enter into force. ${ }^{79}$ The EC does not break any new ground (which has proven difficult in the past when it comes to industrial policy), but examines how Member States can use existing tools to prevent harmful FDI.

The FDI Screening Regulation was adopted in 2019 and enters into force in October $2020 .{ }^{80}$ The Regulation determines how Member States should organize measures preventing or conditioning investments originating from third (ie non-EEA) countries. Only investments that are a potential threat to the 'security or public order' are targeted by the Regulation. In determining whether such a threat is plausible or imminent, they may 'consider all relevant factors, including the effects on critical infrastructure, tech-

78 EC, 'Guidance to the Member States concerning foreign direct investment and free movement of capital from third countries, and the protection of Europe's strategic assets, ahead of the application of Regulation (EU) 2019/452 OJ C 99/1' (Communication) C 1981 [2020] ('FDI Guidance').

79 Commission Regulation (EU) 2019/452 establishing a framework for the screening of foreign direct investments into the Union OJ L 791/1 ('FDI Screening Regulation').

80 ibid, art 16.

81 FDI Screening Regulation, recital 13.

82 FDI Screening Regulation, art 4(1)(b).

83 FDI Guidance, 2

84 The relevant sectors are energy, transport, water, healthcare, communications, media, data storage and processing, aerospace, defense, finance or sensitive installations. Industries that are a part of essential supply chains are also targeted, eg raw materials and food.

85 See Annex to the FDI Guidance.

86 See eg Aitor Hernández-Morales, 'Germany confirms that Trump tried to buy firm working on coronavirus vaccine' (Politico, 15 March 2020) <https://www.politico.eu/article/germany-confirms-that -donald-trump-tried-to-buy-firm-working-on-coronavirus-vaccine/>.

87 See Case C-282/04 Commission v Netherlands [2006] ECR I-9141 nologies ... and inputs which are essential for security or the maintenance of public order'. ${ }^{81}$ In other words, the Regulation is aimed at protecting strategic industries that manage critical infrastructure, such as energy, transport, communications and health services. ${ }^{82}$ Although the Regulation enables the EC to request additional information and to issue certain opinions, the final word on the investment is left to the Member States.

The FDI Guidance interprets the FDI Screening Regulation, at times broadly, so as to offer Member States a clear framework in times when strategic undertakings may be suffering losses/are significantly undervalued, which creates opportunities for foreign acquirers, leading to a corresponding loss of European control. Therefore, the EC urges Member States to intensively use their existing screening mechanisms, in particular for health-related infrastructures, and invites Member States that do not yet have a full-fledged screening mechanism 'to use all other available options' ${ }^{83}$ The Spanish Government, for example, has proactively decided to preclude foreign investors from acquiring more than $10 \%$ of the share capital of an undertaking active in public health or public security. ${ }^{84}$ Even foreign investments under that threshold are in many cases still subject to $e x$ ante authorization. Note that acquisitions of less than $10 \%$ are generally considered 'portfolio investments' that do not grant effective influence and do not constitute an FDI that requires screening. However, the FDI guidance acknowledges that even qualified shareholder rights may be relevant in terms of security or public order and stresses the importance of screening low-rate investments. ${ }^{85}$ Even small investments in SMEs or start-ups may be harmful, given that they have the potential to grow into the EU's future champions.

In the corona crisis, FDI-especially in the healthcare sector (from hospitals to the development of vaccines) - is particularly controversial. ${ }^{86}$ As such, it reopens a difficult debate on industrial policy and the need to protect EU industry from foreign influence. Moreover, FDI screening interacts with a number of branches of EU economic law, including the free movement of capital, merger control, and State aid. Problematically, these different branches each have their own rationale and methods, which may conflict. For example, the use of 'golden shares' to give governments outsized corporate control has been difficult to reconcile with the free movement of capital. ${ }^{87}$ 
Further, the different ways of protecting European undertakings - ie by providing them with State aid or by preventing foreign investment-do not always align, although it is notable that the Second Amendment to the Temporary State Aid Framework (see infra, section IV.) explicitly considers the interaction between them. At the end of the day, however, the main critique of FDI screening still stands: the existing control mechanisms put in place by the Regulation remain rather insignificant and diverge widely. ${ }^{88}$ The corona crisis has not yet spurred the political will to go further on that front.

\section{State Aid: Flexible Lifeline or Obstacle in Times of Crisis?}

The rise of the coronavirus does not only require the monitoring of private conduct; the feared economic crisis also urgently demands active State intervention. ${ }^{89}$ Member States are adopting various measures to compensate for losses suffered due to the outbreak of the virus such as compensation for temporary closure of businesses, ${ }^{90}$ the introduction of State guarantees, ${ }^{91}$ or temporary relief from tax or social security payments. ${ }^{92}$ Increased public spending to compensate for economic harm, as well as to support hospitals and other medical services, raises the question how Member States must comply with EU State aid law in times of corona.

In the past weeks, the EC has shown a hands-on approach. At the start of the crisis, the EU first mobilised and refocused its own existing tools to maximise EU aid, such as investments by the European Investment Bank, the European Investment Fund and structural funds. The EC also announced a 'Coronavirus Response Investment Initiative' with up to $€_{37}$ billion in cohesion funds to combat the economic fallout of the virus. ${ }^{93}$ On 19 March 2020, the EC adopted a Temporary Framework for corona-related State aid ('Temporary State Aid Framework'). ${ }^{94}$

By 19 April 2020, 88 decisions were made based on the Temporary State Aid Framework. However, this string of approval decisions might create the illusion that each aid package must be notified to the EC. This is not the case as Member States may still benefit from existing mechanisms, which have sometimes been overlooked in the numerous discussions of the first version of the Temporary Framework. In addition to recalling the general logic of State aid as- sessments and discussing the new framework, we focus on the first amendment to that framework, which is particularly relevant for financial support for corona-related research.

\section{General State Aid Assessment}

Governments and potential beneficiaries alike are well advised to first categorize their COVID-19 related State measures as follows: (i) State measures that do not require notification with the EC because they do not constitute State aid; (ii) State measures which do not require notification with the EC because, even though they do constitute State aid, they are block exempted; (iii) State aid measures which do require notification.

\section{a. State Measures That Do Not Constitute State Aid}

Many forms of financial support fall outside the scope of EU State aid rules. Firstly, State measures that directly compensate citizens instead of undertakings, such as 'financial support for consumers for cancelled services or tickets that are not reimbursed by the operators, ${ }^{95}$ do not constitute State aid (even though such support could indirectly benefit service providers or event organisers). Similarly, grants to non-economic activities are not State aid either. This

88 See a recent report by Elvire Fabry and Jacopo Maria D'Andria, 'The challenges of Chinese investment control in Europe' Jacques Delors Institute, 11 February 2019).

89 Nikos Chrysoloras, 'Breaking Europe's fall' (Bloomberg, 16 March 2020) <https://www.bloomberg.com/news/articles/2020 -03-16/finance-ministers-seek-to-break-europe-s-fall-brussels -edition>.

90 Denmark - Compensation for companies particularly exposed to COVID-19 outbreak (Case SA.56774) Commission Decision C 2294 [2020].

91 Portugal - Guarantee schemes related to COVID-19 (Case SA.56755) Commission Decision C 1888 [2020].

92 EC, 'Commission approves French scheme deferring payment by airlines of certain taxes to mitigate economic impact of coronavirus outbreak' (Press release, 31 March 2020) IP/20/514.

93 EC, 'Commission sets out European coordinated response to counter the economic impact of the Coronavirus' (Press release, 13 March 2020) IP/20/459.

94 EC, 'Temporary Framework for State aid measures to support the economy in the current COVID-19 outbreak' (Communication) C 1863 [2020].

95 EC, 'Commission sets out European coordinated response to counter the economic impact of the Coronavirus' (Press release, 13 March 2020) IP/20/459. 
includes social security services (including financing of compulsory health insurance), but also several social and welfare services ${ }^{96}$ or services falling within the exercise of public powers. ${ }^{97}$ Furthermore, financial interventions that take the form of general measures, applicable to all undertakings, do not constitute State aid because they lack 'selectivity'. For example, a general suspension of payment of social and tax contributions in times of corona does not constitute State aid. ${ }^{98}$

Still in this category is State compensation for public service obligations or services of general economic interest (SGEIs). The EC defines SGEIs as 'economic activities identified by public authorities as being of particular importance to citizens and that would not be supplied (or would be supplied under different conditions) without public intervention. ${ }^{99}$ The definition leaves Member States much discretion in identifying SGEIs. Several sectors that are particularly affected by corona such as hospital services, elderly care, and residential care fall under the scope of this regime. They can benefit from 'softer' treatment under the ECJ's Altmark judgment ${ }^{100}$ and the EC's Second Altmark Package. ${ }^{101}$ A State measure will not constitute State aid at all and should not be notified as such if it fulfils the criteria set out in the Altmark judgment. This will be the case if (i) the recipient undertaking is required to discharge a clearly defined public service obligation; (ii) the compensation thereof is calculated on the basis of pre-determined objective and transparent parameters, and is proportion-

96 Eg short-term care services are considered non-economic; Germany - State aid for the promotion of public welfare services (Case SA.42268) Commission Decision C 7686 [2017], para 9.

97 Case C-343/95 Diego Cali \& Figli [1997] ECR I-01547; Case T-138/15 Aanbestedingskalender v Commission EU:C:2019:932, para 18.

98 Michael Honoré, 'Selectivity' in Philipp Werner and Vincent Verouden (eds), EU State Aid Control - Law and Economics (Kluwer 2017).

99 EC, 'Services of General Economic Interest' (Opinion Prepared by the State Aid Group of EAGCP, 29 June 2006).

100 Case C-280/00 Altmark Trans and Regierungspräsidium Mageburg [2003] ECR I-07747.

101 The Second Altmark Package consists of four documents: 1. EC, 'The application of the European Union State aid rules to compensation granted for the provision of services of general economic interest' (Communication) OJ C8/4 ('SGEI Communication'); 2. Commission Regulation on the application of Articles 107 and 108 of the [TFEU] to de minimis aid granted to undertakings providing services of general economic interest, OJ L114/8 (SGEI De Minimis); 3. Commission Decision on the application of ate; and (iii) the provider of the public service is selected on the basis of public procurement or benchmarking. ${ }^{102}$

Finally, aid that does not affect trade between Member States or distort competition does not constitute State aid either. This condition is not fulfilled if the aid amount is below the thresholds of the general (€200,000/3 years per undertaking $)^{103}$ and SGEI $\left(€_{500,000 / 3} \text { years per undertaking }\right)^{104}$ de minimis regimes. Therefore, relatively small amounts of aid should not be notified. The scope of the de minimis regimes is more extensive than one would expect. For example, the aid component in an interest subsidy is solely limited to the difference between the market interest rate and the rate applied in the aid measure. ${ }^{105}$ Moreover, authorities can cumulate the de minimis regime with other instruments, as long as the financial support does not alter the conditions of the other exemption, such as the General Block Exemption Regulation (GBER). ${ }^{106}$

\section{b. State Aid That Does Not Require Notification}

Since the completion of the State aid modernisation, most State aid measures are no longer notified to the EC. ${ }^{107}$ As long as they respect block exemption regulations, Member States have wide powers to devise aid measures on their own, without any notification being required. Two such block exemptions regulations should be mentioned. First, the GBER, otherwise the single most important tool for exemption of
Article 106(2) of the [TFEU] to State aid in the form of public service compensation granted to certain undertakings entrusted with the operation of services of general economic interest, $\mathrm{OJ}$ L7/3 ('SGEI Decision'); 4. Commission Decision on the European Union framework for State aid in the form of public service compensation, OJ C8/15 ('SGEI Framework').

102 See the SGEI Communication for more information on these criteria.

103 Commission Regulation on the application of articles 107 and 108 of the [TFEU] to de minimis aid, OJ C352/1 ('General De Minimis'), art 3(2).

104 SGEI De Minimis, art 2(2).

105 ibid, para 17.

106 Eg a cumulation of de minimis and the GBER may exceed certain thresholds regarding aid amount, incentive effects, etc.

107 In 2017, Member States spent €116.2 billion on State aid, with only 230 million of notified aid, see 'State aid scoreboard 2018 ' $<$ https://ec.europa.eu/competition/state_aid/scoreboard/state_aid _scoreboard_2018.pdf > . 
State aid, does not appear to be essential for corona measures. ${ }^{108}$ Second, the SGEI Decision allows for a general compensation up to $€_{15}$ million/year for undertakings entrusted with such a service. ${ }^{109}$ However, and most relevant in the current crisis, no threshold applies to compensation for the provision of SGEIs by 'hospitals providing medical care, including, where applicable, emergency services' or to those 'providing SGEIs meeting social needs as regards health and long term care, childcare, access to and reintegration into the labour market, social housing and the care and social inclusion of vulnerable groups.'. ${ }^{110}$ Therefore, additional costs for eg residential care facilities - which are put under strain by the corona crisis - should not be a major State aid concern. $^{111}$

\section{c. Notification and Exemption Under the Treaty Provisions}

Existing treaty provisions have proven their worth as useful exemptions during the corona crisis. There are three relevant Treaty exemptions for aid in (economic) emergency situations: (i) for 'compensation for damages suffered by natural disasters or exceptional occurrences' (Article 107(2)(b) TFEU); (ii) for 'rescue and restructuring aid' (Article 107(3)(c) TFEU; and (iii) for 'aid to remedy a serious disturbance in the economy' (Article 107(3)(b) TFEU).

\section{i. Aid to Make Good Damage Caused by Exceptional Occurrences}

On 12 March 2020, a first corona aid scheme was notified to the EC. At that time, the Temporary State Aid Framework was not yet in place, and the aid was notified on the basis of Article $107(2)(b)$ TFEU. ${ }^{112}$ Even after the adoption of the Temporary Framework, this Treaty exemption continues to be relied upon frequently, eg in case of the Danish and Swedish compensation for airline SAS. ${ }^{113}$ Importantly, the EC considers corona an 'exceptional occurrence' and not its companion 'natural disaster'. This is relevant because 'compensation for natural disasters' is covered by the GBER (Article 50) and, therefore, does not have to be notified. On the contrary, compensation for 'exceptional occurrences' does have to be notified. By labelling the corona outbreak an 'exceptional occurrence', the EC makes it clear that any compensation measures have to be notified. $^{114}$
Article 107(2) TFEU lists several 'automatic' exemptions which leave less discretion for the EC than in case of 'facultative' exemptions in 107(3) TFEU, as an exemption must be granted as soon as the conditions for applicability are fulfilled. Nevertheless, the EC also checks the proportionality of the aid, ie whether it does not exceed what is necessary to compensate for the damage suffered. ${ }^{115}$ Hitherto, five measures have been approved in accordance with 107(2)(b) TFEU.

\section{ii. Rescue and Restructuring Aid for Individual Companies}

A second Treaty exemption for corona related State aid is Article 107(3)(c) TFEU, which refers generally to 'aid to facilitate the development of certain economic activities'. One of the subcategories under this broad umbrella is rescue and restructuring aid, for which the EC has developed specific Guidelines (both for financial ${ }^{116}$ and for non-financial ${ }^{117}$ undertakings

108 Commission Regulation (EU) 651/2014 declaring certain categories of aid compatible with the internal market in application of Articles 107 and 108 [2014] OJ L187/1. It does not apply to compensation for 'exceptional occurrences', nor to rescue and restructuring aid, and also excludes aid to undertakings in difficulty. See art 1(4)(c). Nevertheless, certain provisions on regional aid and aid to SMEs might be of use, as the Temporary State Aid Framework may be cumulated with the GBER, see EC, 'Amendment to the Temporary Framework for State aid measures to support the economy in the current COVID-19 outbreak' (Communication) C(2020) 2215 final, para 11 (footnote 2).

109 SGEl Decision, art 2(1)(a). Note that, because of its legal basis, it is labelled a 'Decision', but it functions as a block exemption regulation.

110 ibid, art 2(1)(b)

111 Elderly care and (non-specialised) medical services are often considered local and therefore not distorting competition or having an effect on trade between Member States, see Alleged aid to a specialised rehabilitation clinic for orthopaedic medicine and trauma surgery (SA.38035) Commission Decision, para 13.

112 Denmark - Compensation scheme for cancellation of events related to COVID-19 (Case SA.56685) Commission Decision C 1698 [2020].

113 EC, 'Commission approves Danish public guarantee of up to $€ 137$ million to compensate airline SAS for damage caused by coronavirus outbreak' (Press release, 15 April 2020) IP/20/667; EC, 'Commission approves Swedish public guarantee of up to $€ 137$ million to compensate airline SAS for damage caused by coronavirus outbreak' (Press release, 24 April 2020) IP 20/748.

114 As confirmed in 'Notification under Article 107(2)(b) TFEU' $<$ https://ec.europa.eu/competition/state_aid/what_is_new/ Notification_template_107_2_b_PUBLICATION.pdf $>$.

115 Michiel Tjepkema, 'Damages granted by the state and their relation to state aid law' (2013) 12 EStAL 478.

$116 \mathrm{EC}$, 'The return to viability and the assessment of restructuring measures in the financial sector in the current crisis under the State aid rules' (Communication) [2009] OJ C 195/9.

117 EC, 'Guidelines on State aid for rescuing and restructuring nonfinancial undertakings in difficulty' (Communication) [2014] OJ C 249/1. 
in difficulty). These remain unchanged and are complementary to other exemptions, as they concern aid to individual undertakings rather than aid schemes. As is well-known, the EC is very strict towards all forms of 'operating aid' that undertakings need to survive on a day-to-day basis. ${ }^{118}$ In the context of the corona fallout, it is thus uncertain whether this exemption will suffice, as the Temporary State Aid Framework has not yet eased the definition of what constitutes an 'undertaking in difficulty'. ${ }^{19}$

\section{iii. Aid for Serious Disturbance in the Economy of a Member State}

During the 2008-2011 financial crisis, we witnessed a gradual move from State aid measures exempted under Article 107(2) TFEU to measures exempted under Article 107(3). ${ }^{120}$ During the corona crisis, a similar process took place where the first, most urgent, national measures were notified and approved as compensation for exceptional occurrences under $107(2)$, while later measures had to stand the test of

118 It is expected that the Second Amendment will relax several restrictions of the Guidelines, ibid.

119 See ibid, para 20.

120 Bruce Lyons and Minyan Zhu, 'Compensating competitors or restoring competition? EU regulation of state aid for banks during the financial crisis' (2013) 13 Journal of Industry, Competition and Trade 39.

121 José Luis Buendía and Angela Dovalo, 'State aid versus COVID-19 - The Commission adopts a Temporary Framework' (2020) 1 EStAL 3.

122 It is noteworthy that art 108(4) TFEU empowers the EC to adopt regulations and specific exemptions.

123 Temporary State Aid Framework, paras 2-3.

124 The Temporary State Aid Framework is aimed at giving quick and flexible approvals. A standard notification template is renewed regularly and provides for all the necessary questions to be answered, see <https://ec.europa.eu/competition/state_aid/what _is_new/amended_notification_template_TF_coronavirus.pdf $>$.

125 Temporary State aid Framework, para 22(c).

126 EC, 'Guidelines on State aid for rescuing and restructuring nonfinancial undertakings in difficulty' (Communication) [2014] OJ C 249/1.

127 Lower thresholds (of $€ 100,000$ and $€ 120,000$, respectively) are applicable for these sectors. These aid measures are assessed separately. For a recent example, see EC, 'Commission approves amendments to previously approved German schemes to further support economy in coronavirus outbreak' (Press release, 11 April 2020) IP/20/651.

128 EC, 'Commission approves $€ 50$ million Italian support scheme for production and supply of medical equipment and masks during Coronavirus outbreak' (Press release, 22 March 2020) IP/20/507.

129 Germany - Federal Framework 'Small amounts of aid 2020' (SA.56790) Commission Decision C 1953 [2020], para 10.
107(3). During the financial crisis, the EC based its temporary frameworks on this provision. As this provision allows Member States to notify large-scale funding and guarantee schemes, ${ }^{121}$ it does not come as a surprise that the Temporary State Aid Framework also builds on this provision. ${ }^{122}$

\section{The Way Forward: The Temporary State Aid Framework}

On 19 March 2020, the EC established that the corona outbreak is affecting the economy of all Member States. ${ }^{123}$ It follows that the exemption of Article 107(3)(b) TFEU is generally applicable, leading to the adoption of a Temporary Framework to better assess State aid that tackles this 'serious disturbance to the economy.' ${ }^{124}$

\section{a. Temporary State Aid Framework 1.0}

The Temporary State Aid Framework applies to all sectors and all kinds of companies, except for companies that were in difficulty already (ie before 31 December 2019). ${ }^{125}$ Those companies can, however, still receive damage compensation or can benefit from exceptional treatment under the Rescue and Restructuring Guidelines. ${ }^{126}$ The other Treaty exemptions remain fully functional and are to some extent complementary to the exemptions of the Temporary State Aid Framework. The first version of the framework provided more guidance on five kinds of aid measures.

\section{i. Direct Grants and Selective Tax Advantages}

Each aid measure that is granted directly and does not exceed $€ 800,000$ per undertaking may be considered compatible with the internal market. For these measures, as well as for repayable advances and tax advantages, it is further required that (i) the grants should be organised as a scheme, and not as an individual measure; and (ii) specific rules are made for the aqua- and agricultural sector. ${ }^{127}$

An Italian State aid scheme of $€_{50}$ million, supporting the production of masks and medical equipment through direct grants, was notified accordingly. ${ }^{128}$ Another example is the German Federal Framework for cross-sectoral aid to companies having temporary financial difficulties. ${ }^{129}$ As the maximum threshold is set at the amount per undertaking, 
schemes of large amounts may still fall under this category as long as the individual grant is limited.

\section{ii. Loan Guarantees}

The Temporary State Aid Framework provides specific compatibility rules for loan guarantees. Loan guarantees are an appropriate way of ensuring access to liquidity for undertakings in need. The guarantee premiums must respect minimum levels, which are classified as maturity loans of one year, two to three years and four to six years. ${ }^{130}$ The guarantee must also be linked to investment or working capital loans. Finally, the guarantee may not be granted after 31 December 2020 to fall under the regime. ${ }^{131}$ For guaranteed loans that run beyond 31 December 2020, stricter thresholds apply. ${ }^{132}$

\section{iii. Subsidised Interest Rates for Loans}

Aside from direct subsidies to an undertaking, a public authority may also subsidise interest rates that are due. It is, however, not possible to cumulate subsidised interest rates for loans with a guarantee scheme. For subsidised interest rates, the interest rate must follow the 1-year IBOR reference or an equivalent method that is laid down in the Reference Rate Communication. ${ }^{133}$ In addition, a credit risk margin should be included in accordance with the tables of the Temporary Framework. ${ }^{134}$

Most of the formal conditions are similar to loan guarantee schemes: the loan contract may not be signed after 31 December 2020, the loan contract may not exceed six years, and this advantage is excluded for undertakings in difficulty before 31 December
2019. For both guarantees and subsidised interest rates, Member States are free to propose their own methodology, by modulating maturity, pricing and coverage. ${ }^{135}$ It is notable that, so far, 34 of the total approvals involve guarantee schemes.

\section{iv. Guarantees and Loans Channelled Through \\ Credit and Financial Institutions}

The EC anticipated that some forms of State aid, in particular loan guarantees and interest rate subsidies, might indirectly favour banks or other financial service providers. ${ }^{136}$ This indirect aid may not have the purpose of preserving or restoring the viability, liquidity or solvency of the financial institution. The secondary and indirect effects for the financial intermediary must be assessed under the State aid rules for banks, without benefitting from the advantageous qualification of the Bank Recovery and Resolution Framework ${ }^{137}$ or the Single Resolution Mechanism. ${ }^{138}$ The EC has emphasised, however, that direct support for banks should still be notified in accordance with the existing rules on State aid for financial institutions. ${ }^{139}$

\section{v. Short-Term Export Credit Insurance}

The last measure eases the rules on short-term export credit insurance (STEC, which protects undertakings against the risk of payment defaults from overseas customers), which are set out in a specific Communication. ${ }^{140}$ The State aid rules on STECs normally preclude Member States (and State-supported insurers) from backing insurances for marketable risks. Marketable risks are 'risks for which
130 Temporary State Aid Framework, para 25(a).

131 Temporary State Aid Framework, para 25(d).

132 The loan principal may not exceed, alternatively (i) double the annual wage bill of the beneficiary for 2019 ; or (ii) $25 \%$ of the beneficiary's total turnover in 2019. It is possible to go beyond these thresholds, in which case the measures must be objectively justified and proportional.

133 Temporary State Aid Framework, para 25(g); EC, 'Revision of the method for setting the reference and discount rates' (Communication) [2008] OJ C 14/6.

134 The sum of the all-in interest rate and the credit risk margin is expressed as 'BPS' (base rate plus credit risk margin).

135 See eg Spain - Guarantee scheme to companies and self-employed to support the economy in the current COVID-19 outbreak (SA.56803) Commission Decision C 1925 [2020], paras 18-20.

136 Temporary State Aid Framework, para 29
137 Directive 2014/59 (EU) establishing a framework for the recovery and resolution of credit institutions and investment firms [2014] OJ L 173/190.

138 European Parliament and Council Regulation (EU) 806/2014 establishing uniform rules and a uniform procedure for the resolution of credit institutions and certain investment firms in the framework of a Single Resolution Mechanism and a Single Resolution Fund [2014] OJ L 225/1.

139 Such as EC, 'The application of State aid rules to support measures in favour of banks in the context of the financial crisis' (Communication) [2013] OJ L 216/1. According Phedon Nicolaides, 'The Corona Virus Can Infest Banks Too - The Applicability of the EU Banking and State Aid Regimes' (2020) 1 EStAL 29, the Temporary State Aid Framework is not crystal clear on how direct liquidity support for financial institutions should be assessed.

140 EC, 'The application of Articles 107 and 108 of the Treaty on the Functioning of the European Union to short-term export-credit insurance' (Communication) [2012] OJ C 392/1 ('STEC Communication'). 
in principle a market exists, ie there is a private insurance capacity available to cover these risks. ${ }^{141}$ In a revision of 27 March 2020, Member States are exceptionally and temporarily allowed to cover risks falling under that category. ${ }^{142}$ They must demonstrate a market failure, providing sufficient evidence that the private insurance market cannot meet the current demand.

\section{b. The First Amendment: Support for R\&D}

Briefly after its publication, the Temporary State Aid Framework was already amended. ${ }^{143}$ The First Amendment has extended the exempted aid measures by allowing for five other types of aid: ${ }^{144}$ (i) aid supporting research and development (R\&D) for medicines against corona; (ii) aid in favour of the construction and upscaling of testing facilities; (iii) investment aid for the production of relevant medical products; (iv) targeted tax payment deferrals and suspension of social security contributions; ${ }^{145}$ and (v) wage subsidies for employees. ${ }^{146}$

The most eye-catching extension of the Temporary State aid Framework is, without a doubt, the exemption for corona related R\&D aid. Already before the First Amendment, such aid could benefit from the specific R\&D Framework. ${ }^{147}$ Instead of rehashing all the conditions, it is more interesting to pinpoint the most important differences with the aid requirements of the R\&D Framework. First, the First Amendment admits a high aid intensity ${ }^{148}$ : the aid can cov-

141 EC, 'Short-term export-credit insurance' (Communication) [1997] OJ C 281/1. In the STEC-Communication, marketable risks are defined as commercial and political risks with a maximum risk period of less than two years, on public and non-public buyers in the countries listed in the Annex (in which all the EU Member States are listed).

142 EC, 'Commission amends Short-term export-credit insurance Communication in light of economic impact of coronavirus outbreak' (Press release, 27 March 2020) IP/20/542.

143 EC, 'Commission extends Temporary Framework to enable Member States to accelerate research, testing and production of coronavirus relevant products, to protect jobs and to further support the economy in the coronavirus outbreak' (Press release 3 April 2020) IP/20/570.

144 EC, 'Amendment to the Temporary Framework for State aid measures to support the economy in the current COVID-19 outbreak' (Communication) C(2020)2215 final ('First Amendment').

145 First Amendment, para 21. This exemption can even cover deferral payment measures for airports, cf. EC, 'Commission approves Belgian scheme deferring payment by Walloon airports of concession fees to mitigate economic impact of coronavirus outbreak' (Press release, 11 April 2020) IP/20/645. er $100 \%$ of the eligible costs for fundamental research and $80 \%$ of the costs for industrial research. ${ }^{149}$ This is more generous than the normal aid intensity thresholds for R\&D, which are established on the basis of three criteria, namely (i) the closeness of the aid to the market, taking into account the potential higher revenues that can be expected from the aided activities; (ii) the size of the beneficiary, as a proxy for the more acute difficulties faced by smaller undertakings to finance a risky project; and (iii) the acuteness of the market failure, such as the expected externalities in terms of dissemination of knowledge. ${ }^{150}$ Second, the First Amendment introduces an 'incentive effect presumption': if the supported project is set in motion after 1 February 2020 and covers research relating to corona and other relevant antiviral research, ${ }^{151}$ the aid is presumed to have an incentive effect. ${ }^{152}$ On the contrary, when notified under the existing R\&D Framework, the incentive effect must be demonstrated on the basis of (i) the specification of the intended change; (ii) the level of profitability; (iii) the timeframe of cash flows; and (iv) the level of risk involved. ${ }^{153}$ Again, the analysis for corona research thus seems more flexible. Third, the grantee benefitting from 'First Amendment R\&D aid' is obliged to grant non-exclusive licenses under nondiscriminatory market conditions to third parties in the European Economic Area. On this point, the First Amendment is stricter than the R\&D Framework, ${ }^{154}$ but the obligation is not surprising given the current circumstances.
146 First Amendment, para 22. For a recent example, see EC, 'Commission approves $€ 88$ million Hungarian aid scheme supporting researchers and developers in all sectors affected by coronavirus outbreak' (Press release, 17 April 2020) IP/20/695.

147 EC, 'Framework for State aid for research and development and innovation' (Communication) OJ 198/1 ('R\&D Framework').

148 This is the gross aid amount expressed as a percentage of the eligible costs, before any deduction of tax or other charge.

149 First Amendment, para 19. In case of joint support by multiple Member States, the intensity of aid for industrial research may increase to $95 \%$.

150 R\&D Framework, para 74.

151 This category covers research for vaccines, medicinal products and treatments, medical devices and hospital and medical equipment, disinfectants, and protective clothing and equipment, and into relevant process innovations for an efficient production of the required products.

152 First Amendment, paras 18-19.

153 R\&D Framework, para 67.

154 In the R\&D Framework, the right to license is repeatedly emphasized. 


\section{c. The Second Amendment: The Road to Protectionism?}

On 9 April 2020, the EC sent a new consultation to the Member States to further extend the scope of the Temporary State Aid Framework. ${ }^{155}$ The Second Amendment would allow for further support through equity and capital instruments. At the time of writing, the new extension has not yet been published. It is expected that the Second Amendment will be crucial to ensure the long-term viability of companies, focussing among others on capital injections. While the amendment is not yet publicly available, the EC is currently exploring whether to prohibit bailed-out undertakings from paying dividends and bonuses. ${ }^{156}$ Furthermore, the rules will be aimed at incentivizing companies to exit the aid schemes as soon as possible, in order to prevent an undue distortion of competition.

This broadening of scope would be necessary for public authorities to prevent hostile takeovers of vulnerable companies by foreign purchasers. Already on 25 March 2020, the EC issued guidelines to tackle potential threats by foreign bidders. ${ }^{157} \mathrm{New}$ exemptions for capital injections will therefore be indispensable in future debates on FDI, the free movement of capital, and how to protect European businesses in the aftermath of the corona crisis. It demonstrates, once again, how State aid control is not just a cog in the wheel.

\section{Free Movement: Public Health Exceptions as Safe Havens?}

Corona is not only stress-testing our competition laws but also the free movement provisions. Can individual Member States, without consulting other Member States or the EC, simply ban the export of medicines or facemasks? Can they close their borders for EU citizens? These and many other questions relate to the four freedoms of the EU's internal market.

\section{Free Movement of Capital}

Of these freedoms, free movement of capital is probably least affected, at least within the EU, because of the intangible nature of capital flows. Although coro- na has a devastating effect on stocks and markets worldwide, this is not the consequence of Member State measures specifically targeting investment from other Member States. However, the free movement of capital may become more important in relation to investments from outside the EU, especially if the corona crisis serves as a catalyst for initiatives limiting the influx of FDI in strategic industries, both during and after the crisis. Such initiatives have already been discussed above (see supra, section III.) and will therefore not be retouched upon in this section. The other three freedoms, however, are also affected to a significant extent even between Member States.

\section{Free Movement of Goods}

Free movement of goods raises many questions. Several categories of national measures raise doubts as to their compatibility with the relevant Treaty Articles (28-36 TFEU): export bans, rationing of goods, shop closures, product and sales restrictions, and price measures.

\section{a. Export Bans and Export Restrictions}

Several Member States have imposed export bans on goods related to the corona crisis, also targeting export to other EU Member States. France, Germany and the Czech Republic, for example, have introduced export bans on protective material such as facemasks. ${ }^{158}$ The measures go against the spirit of free movement and the internal market, but do they also breach EU law? Export bans fall under Article

\footnotetext{
155 EC, 'Coronavirus: Commission Statement on consulting Member States on proposal to further expand State aid Temporary Framework to recapitalisation measures' (Statement, 9 April 2020) $<$ https://ec .europa.eu/commission/presscorner/detail/en/STATEMENT_20_610>.

156 Javier Espinoza, 'EU bars bailed-out companies from paying dividends and bonuses' (Financial Times, 15 April 2020) <https:// www.ft.com/content/57e4ef47-8589-4431-a4f4-36edc8c23a70>.

157 EC, 'Guidance to the Member States concerning foreign direct investment and free movement of capital from third countries, and the protection of Europe's strategic assets, ahead of the application of Regulation (EU) 2019/452' (Communication) C/2020/1981.

158 Francesco Guarascio and Philip Blenkinsop, 'EU fails to persuade France, Germany to lift coronavirus health gear controls' (Reuters, 6 March 2020) <https://www.reuters.com/article/us-health -coronavirus-eu/eu-fails-to-persuade-france-germany-to-lift -coronavirus-health-gear-controls-idUSKBN20T166>.
} 
35 TFEU, which prohibits '[q]uantitative restrictions on exports, and all measures having equivalent effect ... between Member States.' An outright export ban qualifies as a 'quantitative restriction', while measures hindering exports or subjecting exports to a permission are also in principle prohibited as 'measures having equivalent effect to a quantitative restriction'. Whereas older ECJ case law had created the impression that Article 35 only targeted discriminatory export restrictions, imposing a difference in treatment between domestic trade and export trade to the detriment of the latter, ${ }^{159}$ we now know that all State measures-even if indistinctly applicable - that negatively affect export trade more than domestic trade are in principle prohibited. ${ }^{160}$

The French, German and Czech (or all other) export bans or restrictions can in principle be justified on grounds of 'protection of health and life of humans', one of the justification grounds explicitly mentioned in Article 36 TFEU. However, it is too often forgotten that even export bans that protect public health will under EU law only be accepted if they (i) are proportionate, ie they are suitable and no less restrictive alternative is available; and (ii) do 'not constitute a means of arbitrary discrimination or a disguised restriction on trade between Member States'. In our view, if a genuine, verifiable shortage for certain protective materials such as facemasks arises in a Member State, that Member State can-subject to the above conditions-successfully invoke Article 36 TFEU to impose an export ban on those materials.

Similar questions might arise if a shortage of medicine or vaccine might one day occur in the framework of the fight against corona. The virus is already affecting the manufacturing capacity and the supply

\footnotetext{
159 Eg Case C-15/79 Groenveld 1979] ECR I-3409, para 9.

160 Eg Case C-205/07 Gysbrechts [2008] ECR I-9947, paras 43-44.

161 Francesco Guarascio, 'Europe could face more drug shortages as coronavirus squeezes supplies' (Reuters, 5 March 2020) <https:// www.reuters.com/article/us-health-coronavirus-eu/europe-could -face-more-drug-shortages-as-coronavirus-squeezes-supplies -idUSKBN20S1R2>.

162 Belgian Constitutional Court, case 146/2019, Tobufar and others [2019].

163 EC, 'Guidelines on the optimal and rational supply of medicines to avoid shortages during the COVID-19 outbreak' (Communication) C(2020) 2272 final.

164 Elisa Braun, 'France slaps price control on hand sanitizer' (Politico, 4 March 2020) <https://www.politico.eu/article/france-slaps -price-controls-on-hand-sanitizer/>.
}

of (Chinese and Indian) ingredients for medicines (which, by the way, leads to calls for less dependence on third countries and might therefore impact the EU's future industrial policy in this area). ${ }^{161}$

In any case, medicine shortages were already high on the agenda before the pandemic. Parallel trade-the trade in products which takes place outside the official distribution system set up by a particular firm - is quasi 'holy' in EU internal market and competition law, but it can have perverse effects when it concerns pharmaceuticals. Member States where prices are relatively low may, because of parallel trade towards Member States with higher prices, be confronted with severe shortages. States have implemented a range of tools to fight medicine shortages ranging from duties to report shortages, over duties to keep stocks and fulfil public service obligations, to the power to fine producers and distributors in case of shortages. Export bans can constitute another tool but they are subject to the conditions set out above. The Belgian Constitutional Court, for example, has recently annulled an export ban because it was insufficiently motivated. ${ }^{162}$ In the Court's view, scientific proof of actual and sufficiently serious shortages was lacking, so that the Act of Parliament could not even be qualified as 'suitable' to reach the aim of protection of human health.

Recently, the EC issued 'Guidelines on the optimal and rational supply of medicines to avoid shortages during the COVID-19 outbreak'. ${ }^{163}$ In these Guidelines, the EC urges Member States to lift unjustified export bans, as they can easily lead to inequitable supply and shortages in the EU. What exactly constitutes an 'unjustified export ban' is not specified by the Guidelines. While the EC does express that total export bans for medicines are definitely not in line with the Treaty, further interpretation is left to the Member States. However, even with regard to justified export bans, the EC pleads for solidarity and encourages Member States to lift these as well, as they are 'detrimental to the availability of medicines even when they are legally justifiable’.

\section{b. Other Measures: Rationing of Goods, Shop Closures, Product and Sales Restrictions, Price Measures...}

In France, the government has ordered that facemasks will only be made available on prescription. ${ }^{164}$ France has also imposed a maximum price for disin- 
fectant hand sanitizers. ${ }^{165}$ Another Member State could impose certain product quality or even labelling requirements (eg a clear warning on cleaning products that bacterial disinfectants cannot kill a virus). Which of those measures are legal under EU law, and which are not? The following reasoning should in our opinion apply. First and foremost, EU harmonisation measures should be applied where they exist (however counterintuitive this may feel, as the TFEU ranks higher in the hierarchy of norms than secondary legislation with harmonisation measures). ${ }^{166}$ Then, measures that determine how masks or gels or other goods are sold (eg only in pharmacies, only on prescription) may escape EU free movement law altogether if they fulfil the socalled Keck criteria, ie they are generally applicable, they do not discriminate products from other Member States in law or in fact and, therefore, do not hinder these products' access to the market. ${ }^{167}$ National measures forcing producers to adapt their product (eg by imposing specific product characteristics, specific packaging or labelling) remain unwelcome, and will only be tolerated if justified and proportionate. Finally, price measures and restrictions on use (eg a national measure which would allow citizens to buy facemasks but not to wear them as long as they are not available for everyone) follow a similar regime, but with a special focus on whether or not they hinder access of foreign products to the market. In this regard, imposing maximum prices is much less dangerous to the internal market (and to free competition-yet another interesting bridge between competition and internal market law, which are closely connected) than imposing minimum or fixed prices, and will therefore be much easier for Member States to justify.

Let us conclude by applying the above theory to the example of government measures ordering shop closure. Several Member States have ordered restaurants and pubs to close down completely, in order to contain the spreading of the virus. Others, like Italy, went further and order the complete closure of all shops except those that are most necessary for the supply of food and medicines. Still others, like Belgium, (used to) combine a total closure of restaurants and pubs with the obligation for other, non-essential shops to close only during the weekend. Are these measures legal under EU law? We believe that they are, but on varying grounds. A measure ordering the closure of shops during the weekend, even if it were imposed on a permanent basis (quod non), reminds us of the ECJ's 'Sunday trading' judgements in the run-up to the 1992 Keck judgement ${ }^{168}$ as well as similar cases after Keck and applying Keck. ${ }^{169}$ Since Keck, and to the extent that the Keck conditions are fulfilled (see above), such national measure would not even come under the scope of Article 34 TFEU and Member States would therefore have the freedom to impose them. The ECJ will not systematically refer to Keck when applying it. ${ }^{170}$ The ECJ may refer to 'insignificant effects' or to effects 'too uncertain and indirect' instead, or it may simply copy Keck without reference, but the outcome remains the same: Member States enjoy autonomy. On the other hand, national measures that order more general shop closures for longer periods, may end up hindering access of products from other Member States. Such measures will therefore not be excluded from the scope of Article 34 TFEU but can still be justified under Article 36, under the conditions set out above.

\section{Free Provision of Services}

A wide range of services has been put on hold by Member States in order to prevent the further spread of the virus. Greece has shut down tourist facilities and hotels; Italy prohibits sporting activities and closed sports clubs; Belgium bans festivals for the summer-and so on. ${ }^{171}$ When prohibiting services or imposing requirements for providers with regard to security and health, Member States have to take

165 'France to regulate price of hand sanitizers amid coronavirus outbreak' (France 24, 4 March 2020) <https://www.france24.com/ en/20200304-france-to-regulate-price-of-hand-sanitisers-amid -coronavirus-outbreak>

166 The ECJ's case law is well established on this point, see eg Case C-5/77 Tedeschi [1977] ECR I-1555, para 35 and Case C-322/01 Deutscher Apothekerverband [2003] ECR I-14887, para 64.

167 Case C-267/91 Keck [1993] ECR I-6097, paras 16-17.

168 Case C-145/88 Torfaen [1989] ECR I-3851, para 17.

169 Case C-69/93 Punto Casa [1994] ECR I-2355, para 12; Case 483/12 Pelckmans EU:C:2014:304, para 24.

170 Thomas Horsley, 'EU law, Sunday trading restrictions ... and the Charter?' (European Law Blog, 19 May 2014) <https:// europeanlawblog.eu/2014/05/19/eu-law-sunday-trading -restrictions-and-the-charter/>.

171 Gerardo Fortuna, 'Very few businesses open up again, as "phase two" is still under study' (Euractiv, 14 April 2020) <https://www .euractiv.com/section/health-consumers/short_news/italy-update -covid-19/>; Sarantis Michalopoulos, 'As Greece joins lockdown club, unions criticise government's new wage-reduction provision' (Euractiv, 27 March 2020) <https://www.euractiv.com/ section/health-consumers/short_news/greece-update-covid-19/>. 
into account the free provision of services. ${ }^{172}$ As a general rule, Member States should not put restrictions on the freedom to provide services with regard to EU service providers who provide services in other Member States than in which they are established. ${ }^{173}$ Yet, both under Article 52 TFEU and Article 16 of the Services Directive, Member States can justify their measures on grounds of public health. The Services Directive further specifies that the measures should in any case not be discriminatory and should still pass the classic proportionality test. ${ }^{174}$

Importantly, most Member States do allow a series of essential services to continue to be provided: hospitals, post offices and other service providers are often still running. In that regard, the EC urges the Member States to ensure that border control measures do not disrupt the provision of these essential services. ${ }^{175}$ It likewise encourages professional travel to ensure that the providers of these services can still operate. ${ }^{176}$ What 'essential services' are, seems to be left to the discretion of the Member States. The EC does offer a few examples, including child care and elderly care.

\section{Free Movement of EU Citizens and Workers}

\section{a. Free Movement of Citizens}

In response to the coronavirus threat, several Member States (such as Austria) introduced health checks at their borders, ${ }^{177}$ while others (such as Denmark,
Poland and the Czech Republic) closed their borders. ${ }^{178}$ At first sight, these measures appear to breach the EU's citizenship provisions, given that the Citizenship Directive stipulates that 'Member States shall grant Union citizens leave to enter their territory with a valid ID card or passport.'. ${ }^{\text {179 }}$

This principle is however not absolute and allows for exceptions. Member States may restrict the freedom of movement of citizens on grounds of public policy, public security and public health. ${ }^{180}$ Interestingly, only the measures taken on grounds of public policy or public security-not public health-have to comply with the principle of proportionality. ${ }^{181}$ The Directive further specifies which diseases can justify measures restricting freedom of movement, namely (i) the diseases with epidemic potential as defined by the relevant instruments of the WHO; (ii) and, under some further requirements, infectious or contagious parasitic diseases. ${ }^{182}$

Contrary to the public security and public policy exceptions, the ECJ has not yet been asked to interpret the public health exception within the context of the free movement of citizens. This is surprising, since scholars point to the fact that the category of 'infectious or contagious parasitic diseases' is particularly_if not overly-broad. ${ }^{183}$ As a consequence, rather delicate scenarios in which a Member State considers HIV an infectious or parasitic disease might occur. Additionally, the current Directive does not include an annex on diseases, as was the case for its predecessor. ${ }^{184}$ Nonetheless, it goes without saying that the coronavirus has 'epidemic potential' - in March, the WHO even characterized the virus as pan-

\footnotetext{
172 TFEU, art 56; Directive of the European Parliament and of the Council (EC) 2006/123 on services in the internal market [2006] OJ L376/36 ('Services Directive'), art 16. health and ensure the availability of goods and essential services' (Communication) C(2020) 1753 final.

177 François Murphy, Sandra Maler, Chris Reese, 'Austria introducing "spot" health checks at Italian border' (Reuters, 6 March 2020) $<$ https://www.reuters.com/article/us-health-coronavirus-austria/ austria-introducing-spot-health-checks-at-italian-border -idUSKBN20T2RV>.

178 Michael Peel, Richard Milne, James Shotter, 'Denmark, Poland and Czechs seal borders over coronavirus' (Financial Times, 13 March 2020) <https://www.ft.com/content/4e89ec5c-6565-11ea -b3f3-fe4680ea68b5>.
}

179 Directive of the European Parliament and of the Council (EC) 2004/58 on the right of citizens of the Union and their family members to move and reside freely within the territory of the Member States [2004] OJ L229/35 ('Citizenship Directive'), art 5.

180 ibid, art 27(1).

181 ibid, art 27(2); Case C-184/16 Petrea EU:C:2017:684, para 39

$182 \mathrm{ibid}$, art 29(1). For the relevant WHO instruments, see WHO, International Health Regulations (3rd edition, 2016) <https://www .who.int/ihr/publications/9789241580496/en/>.

183 Kristine Kruma, EU Citizenship, Nationality and Migrant Status An Ongoing Challenge (Martinus Nijhoff Publishers 2014), 188; Solange Maslowski, 'The Expulsion of European Union Citizens from the Host Member State: Legal Grounds and Practice' (2015) 4(2) CEEMR 61, 64

184 Council Directive (EEC) 64/221 on the co-ordination of special measures concerning the movement and residence of foreign nationals which are justified on grounds of public policy, public security or public health [1964] OJ 850/64. 
demic. ${ }^{185}$ Therefore, the measures taken by Denmark, Poland, the Czech Republic and others seem to comply with the EU's citizenship provisions.

However, border control measures also need to be 'Schengen proof'. Schengen-area Member States have the right to reintroduce border controls when there is a serious threat to public policy or internal security in a Member State (public health is not specifically in the list of exceptions). ${ }^{186}$ In addition, the border controls have to be proportionate, time limited and a last resort option. ${ }^{187}$ Earlier examples of these exceptions are terrorist threats and secondary movements within the context of migration. In its 'Guidelines for border management measures to protect health and ensure the availability of goods and essential services', the EC confirms that Member States may reintroduce temporary border controls at internal borders if justified for reasons of public policy or internal security, but this should be notified. ${ }^{188}$ Accordingly, several Schengen Member States have already notified a temporary reintroduction of border control until mid or late June. ${ }^{189}$

\section{b. Free Movement of Workers}

As a result of lockdowns in various EU Member States, many cross-border workers can no longer perform their jobs. Hence, these measures raise questions with regard to the free movement of workers enshrined in Article 45 TFEU. $^{190}$ Austria, for instance, only allows cross-border workers to enter the country with a medical certificate. ${ }^{191}$ Member States however have to ensure that workers from a certain Member State can seek and accept work in another Member State. These workers have the right to the same treatment as national workers. Any form of direct or indirect discrimination (eg the medical certificate at the border) is prohibited. Nevertheless, these measures can still be justified on grounds of public health. ${ }^{192}$ The traditional free movement reasoning, including a proportionality test, thus applies.

On 30 March 2020, the EC issued guidance to en sure the free movement of critical workers. ${ }^{193}$ The list of workers that exercise critical occupations is not exhaustive and includes, for instance, health associate professionals, fire fighters and police officers. Beyond these specific categories of workers, the EC stressed that 'Member States should allow frontier workers in general to continue crossing borders if work in the sector concerned is still allowed in the host Member State. Member States should treat cross-border workers and national workers in the same manner'. As a consequence, health screening should be carried out under same conditions for both cross-border workers and national workers exercising the same occupation, and thus not only for crossborder workers. According to the EC, health screenings can be carried out before or after crossing the border. However, if the screenings would only take place before the border, this might de facto result in only cross-border workers being screened, as national workers do not have to cross a border. Similar concerns rise when the screenings would take place after crossing the border, but would only be carried out for cross-border workers.

\section{Public Procurement: Between 'Mere' and 'Extreme' Urgency}

In normal times, state authorities must respect strict tendering procedures when acquiring certain goods, works or services. Traditionally, public authorities do not enjoy the same freedom of contract as private undertakings or as their citizens. These stringent guidelines - imposed by a number of EU harmoni-

$185 \mathrm{WHO}$, 'WHO Announces COVID-19 outbreak as pandemic' (WHO Europe, 12 March 2020) <http://www.euro.who.int/en/ health-topics/health-emergencies/coronavirus-covid-19/news/ news/2020/3/who-announces-covid-19-outbreak-a-pandemic $>$.

186 Regulation of the European Parliament and of the Council (EU) 2016/399 on a Union Code on the rules governing the movement of persons across borders (Schengen Borders Code) [2016] OJ $\mathrm{L} 77 / 1$, art 25(1).

187 ibid, art 25(2).

188 EC, 'Guidelines for border management measures to protect health and ensure the availability of goods and essential services' (Communication) C(2020) 1753 final.

189 EC, 'Member States' notifications of the temporary reintroduction of border control at internal borders pursuant to Article 25 and 28 et seq. of the Schengen Borders Code' <https://ec.europa.eu/ home-affairs/sites/homeaffairs/files/what-we-do/policies/borders -and-visas/schengen/reintroduction-border-control/docs/ms _notifications_-_reintroduction_of_border_control_en.pdf $>$.

190 TFEU, art 45; Regulation of the European Parliament and of the Council (EU) 492/2011 on freedom of movement for workers within the Union [2011] OJ L141/1.

191 Nik Martin, 'As EU borders are shut, frontier workers feel the pain' (DW, 12 March 2020) <https://www.dw.com/en/cross -border-workers-coronavirus-pandemic-italy-switzerland-austria -germany-quarantine/a-52737342>.

192 TFEU, art 45(3); Case C-237/94 O'Flynn EU:C:1996:206 [1996] ECR I-2617, para 26.

193 EC, 'Guidelines concerning the exercise of the free movement of workers during COVID-19 outbreak' (Communication) 2020/C $102 \mathrm{l} / 03$. 
sation instruments ${ }^{194}$ — are motivated by efficiency (as goods or services are acquired with taxpayers' money, good governance requires an objective selection of the best offer) as well as fairness considerations (the level playing field objective of the EU's internal market policies trickling down to the award of public contracts). ${ }^{195}$

In practice, this requires an interplay of several procedural and substantive requirements, such as EU-wide publication obligations, ${ }^{196}$ a limited list of possible procedures, ${ }^{197}$ mandatory exclusion grounds for certain candidates, ${ }^{198}$ and limited awarding criteria. ${ }^{199}$ And even if the EU's public procurement regime only applies to contracts with a value above certain minimum thresholds, ${ }^{200}$ Member States are still free to apply national rules for less significant contracts. Moreover, general principles of EU (public procurement) law might still apply, regardless of the low value of the underlying contract. ${ }^{201}$ In general, the award of a public contract is thus to be handled with the necessary amount of (legal) care.

Albeit that these requirements are understandable and even laudable in normal times, governments - in their capacity as crisis manager-sometimes have to acquire goods without delay. As shown during the corona crisis, certain crucial items (facemasks, test kits, ventilators) can be in high demand worldwide. For these scenarios, public procurement law has two types of slimmed-down regimes, depending on the level of urgency faced by the contracting authorities.

The first and most exceptional regime is available to contracting authorities in cases of 'extreme ur-

\footnotetext{
194 The most important one being Directive 2014/24/EU of the European Parliament and of the Council of 26 February 2014 on public procurement, OJ 2014 L 94/65 ('Procurement Directive').

195 See Sue Arrowsmith, 'The purpose of the EU Procurement Directives: ends, means and the implications for national regulatory space for commercial and horizontal procurement policies' (2011-2012) 14 Cambridge YB Eur Legal Stud 1.

196 Procurement Directive, s 2.

197 The main division is between 'open procedures' (ibid, art 27), ie no prior selection of candidates, and 'restricted procedures' (art 28), ie candidates have to pass a selection stage before submitting a tender. When necessary and provided the fulfilment of certain requirements, specific types of procurement procedures might become available, eg competitive procedure with negotiation (art 29), competitive dialogue (art 31), innovation partnership (art 31). The most relevant procedure for the scope of this article is the negotiated procedure without prior publication (art 32).
}

198 ibid, art 57. gency'. This state is caused by events unforeseen by the contracting authority, and that may in no way be attributable to it. ${ }^{202}$ In its case law, the ECJ-based on the wording of the relevant provisions (eg 'strictly necessary ${ }^{203}$ ) - has narrowly construed this exception. This strict reading was showcased when Germany tried to invoke an 'unforeseen' rejection of a dredging project by a local authority. The Court, however, did not accept this reasoning as it was wellknown that - even if this was rather rare-such a refusal was within the powers of the local body. ${ }^{204}$ Moreover, the burden of proof regarding the extremely urgent nature of a situation lies with the contracting authority. ${ }^{205}$ If the government does not provide support for their claim of extreme urgency, the recourse to this regime will be held unlawful.

Concretely, when the conditions for extreme urgency are met, a rare type of awarding procedure becomes available: the negotiated procedure without prior publication. ${ }^{206}$ This empowers contracting authorities to select one or multiple undertakings, and to immediately negotiate on a future offer and contract. In practice, this implies that a European-wide publication notice is no longer required (or only in a less burdensome manner), and that the contact between the contracting authority and the selected contractual counterpart(s) may be more intense and/or informal.

A second category of situations softening the requirements of public procurement law is the so-called 'state of urgency duly substantiated by the contracting authority'. The requirements for recognition thereof are far less stringent (the urgency may,

$199 \mathrm{ibid}$, art 67. One of the main conditions, when opting for the use of the 'most economically advantageous' criterion (instead of price) is that the award criteria should be 'linked to the subjectmatter of the public contract'. See Marc Martens and Stanislas De Margerie, 'The link to the subject-matter of the Contract in Green and Social Procurement' (2013) 8 EPPL 8, 17.

200 Procurement Directive, art 4.

201 Case C-324/98 Telaustria [2000] ECR I-10745, paras 60-62.

202 Procurement Directive, consideration 50.

203 Procurement Directive, art 32(c).

204 Case C-318/94 Commission v Germany [1996] ECR I-01949, paras 18-19.

205 Cases C-20/01 and C-28/01 Commission v Germany [2003] ECR I-03609, para 58

206 See Procurement Directive, art 32; this type of procedure is not only available in cases of extreme urgency, but also when in following a more standard procedure no (suitable) tenders have been submitted, or when a project can only be carried out by one specific economic operator 
for example, be attributable to the authority). Conversely, the exceptions to the general public procurement regime are also of a more limited nature. The most common consequence of such a state of 'mere' urgency is the reduction of time limits: (i) if the contract is awarded through an open procedure (ie all candidates can immediately propose an offer), the minimum period between notification of the contract and the required response is reduced from 35 to 15 days; $;^{207}$ or (ii) if a restricted procedure is selected (ie the authority first selects a number of candidates, and only these can send in an offer), the time limit between the information notice and the application is limited from 30 to 15 days, whereas the subsequent period between the invitation to tender and the offer is reduced from 30 to 10 days. ${ }^{208}$ The most important requirement is that the application of the shorter deadlines is motivated in the tendering documents.

The EC has confirmed that both procedures are available to contracting authorities responding to the corona crisis. In its guidance, the EC mainly focuses on the flexibility of the negotiated procedure without publication:

In practice, this means that authorities can act as quickly as is technically/physically feasible - and the procedure may constitute a de facto direct award only subject to physical/technical constraints related to the actual availability and speed of delivery. ${ }^{209}$

According to the EC, all the substantial requirements to use these procedures are-given the corona context—presumed to be fulfilled. ${ }^{210}$ Governments are thus awarded a quasi-carte blanche from a public procurement perspective when trying to acquire certain necessary goods or services. Importantly, however, the question remains what the exact legal impact is of this guidance. ${ }^{211}$

Unfortunately, suppliers might be inclined to turn this crisis to their advantage. In Poland, for example, producers of protective equipment terminated a number of contracts with hospitals, hoping to re-enter them under more lucrative conditions. ${ }^{212} \mathrm{Howev}$ er, this type of behaviour, might not be without consequences. First, the Procurement Directive includes a specific exclusion ground from future tender procedures when 'the economic operator has shown significant or persistent deficiencies in the performance of a substantive requirement under a prior public contract'. ${ }^{213}$ Moreover, these actions might also be scrutinized from a competition law perspective. The termination of the public contracts could indeed (when holding a dominant position) be held abusive under Article 102 TFEU. This explains why the Polish competition authority is taking the lead regarding the breach of supply contracts with certain hospitals. ${ }^{214}$ Even if the current urgent situation provides authorities with a (necessary) amount of legal flexibility, the contractual counterparts are thus not completely off the leash: public procurement, in interaction with other legal regimes, still provides a number of necessary checks and balances. ${ }^{215}$

\section{Conclusion}

Since early March 2020, Member States have been scrambling to formulate an effective response to the coronavirus outbreak. The strategies they come up with often raise questions under EU economic law; suddenly, the cornerstones of free competition and free movement are under intense pressure. However, the EC demonstrated decisiveness in setting out a framework that helps to protect the fundamental pillars of the EU while also being sufficiently flexible to accommodate the initiatives of Member States and undertakings. Even though the guidance from

207 Procurement Directive, art 27(3).

208 Procurement Directive, art 28(6).

209 EC, 'Guidance from the European Commission on using the public procurement framework in the emergency situation related to the COVID-19 crisis' (Communication) OJ 2020 C 108 I/1, 2.

210 ibid, 2-4.

211 The EC itself limits the reach of its guidance (ibid, footnote 1): 'This guidance reflects the Commission's understanding of the Treaties, the public procurement directives and the case-law of the Court of Justice of the European Union (the Court). It should be noted that, in any event, the binding interpretation of Union law is ultimately the role of the Court of Justice of the European Union. The guidance does not change the legal framework.'

212 Polish Office of Competition and Consumer Protection, 'UOKiK's proceedings on wholesalers' unfair conduct towards hospitals' (Press release, 4 March 2020) <https://www.uokik.gov.pl/news .php?news_id=16277>.

213 Procurement Directive, art 57(4)(g).

214 Polish Office of Competition and Consumer Protection, 'UOKiK's proceedings on wholesalers' unfair conduct towards hospitals' (Press release, 4 March 2020) <https://www.uokik.gov.pl/news .php?news_id=16277>.

215 Of course, public procurement law also mitigates the difficult situation for contractual counterparts during a crisis such as the corona pandemic (eg through hardship clauses). The analysis of these mechanisms is, however, beyond the scope of this article. 
the EC at times did not offer more than an overview of existing (case) law and administrative practice (eg with regard to public procurement), it has generally proven effective in giving sufficient leeway while also protecting EU fundamentals. For example, the EC has been deferential to the public health concerns relied on by Member States and undertakings to justify initiatives that may restrict free movement or competition, but has not refrained from carrying out proportionality assessments.

However, flexibility comes at a cost: where the boundaries of the law stretch, policy and politics come to the fore. State aid is the prime example. It is increasingly clear that there are significant asymmetries between Member States when it comes to the amount of aid granted (half of the aid approved by the EC during the corona crisis is granted by Germany). In addition to increasing regional inequality, such asymmetries can lead to long-term distortions of competition in the internal market, which is precisely what the State aid rules aim to prevent. More- over, the asymmetry is not only felt by Member States, but also by undertakings, such as independent' airlines that complain of discrimination in comparison to (formerly) national airlines. It is also worth noting that many of the EC decisions (also beyond State aid) can be appealed to the General Court, where a 'second wave' can thus be expected.

The corona crisis has also shown the interconnectedness between free competition and free movement - a unique characteristic of the European (economic) project. For example, the EU's industrial policy has always been fragmented throughout the various branches of law. The corona crisis appears to trigger a degree of convergence between merger control (the FDI regime), State aid (the Second Amendment), and the free movement provisions (the freedom of capital).

Finally, it remains to be seen whether national governments can agree on more sweeping proposals to combat the long-term economic and financial effects of the corona crisis. 